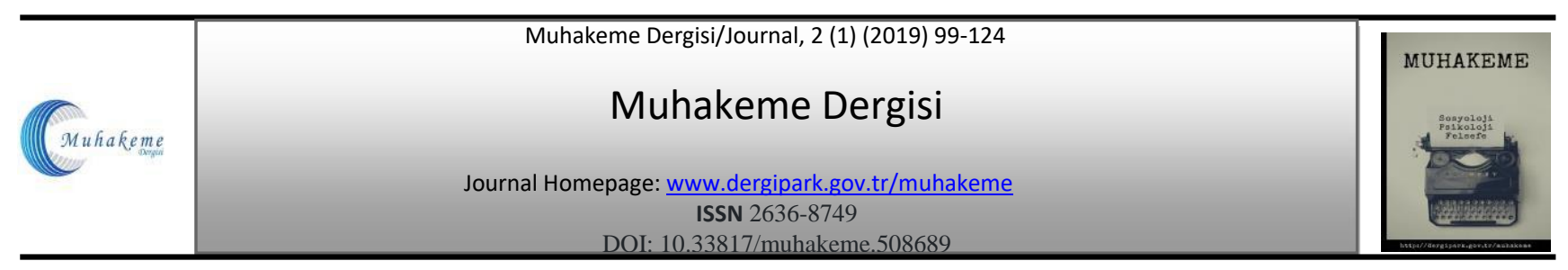

\title{
Savaş, Kadın, Çocuk ve Göç Üzerine: Suriye Örneği
}

Mehmet KARANFÍLOĞLU ${ }^{1}$

\section{ÖZET}

Suriye'deki iç savaş, 2011 yılından beri ülkemizin ve dünya gündeminin en önemli sorunlarından biri haline gelmiştir. Muhalif güçlerin protestoları ile başlayan süreç yaklaşık 7-8 yıldır birçok insan hayatına mal olmuş, şehirleri viran hale getirmiştir. Bu süreçte birçok Suriyeli zorunlu olarak göç etmeye mahkûm edilmiştir. Yaşanan bu zorunlu göç sırasında kadın-erkek, genç-yaşlı, zengin-fakir birçok kesimin hayatı tamamıyla değişmiştir. Öte yandan savaş ve göç olgusu insanlık tarihi kadar eskilere dayanmakta, ilk olarak ne zaman başladığı bilinmemektedir. Zaten hem akademik alanda hem siyasi alanda hem de toplum nezdinde yüzyıllardır tartışılmakta olan bu iki önemli konu, Suriye iç savaşı ile birlikte birçok ülkenin ana gündem maddelerinden biri haline dönüşmüştür. Bugünlerde Suriye ile ilgili herhangi bir konuda haber yapılmayan, gelişmelerin medyaya yansımadığı bir gün bile geçmemektedir. Özellikle kadın ve çocukların yaşadıkları ve maruz kaldıkları olumsuz hatta insani olmayan olaylar ve durumlar bilhassa Türkiye'nin en önemli sorunu olarak görülmektedir. Milyonlarca göçmen Suriyeli kadın ve çocuk, kayıtlı veya kayıtsız olarak Türkiye'ye sığınmış ve bu durum birçok sorunu hem Türkiye vatandaşları hem de Suriye vatandaşları perspektifinde ele alınmasını zorunlu hale getirmiştir. Bu çalışma ile amaçlanan göç ve savaş konuları kapsamında Suriyeli göçmen kadın ve çocuklara yönelik yapılan araştırma bulgularının ortaya konulması ve tartışılmasıdır. Bu bağlamda yapılan bu çalışmada önce literatür taraması ile kavram ve konulara yer verilmiş sonra da tamamlanan araştırma sonucu ile elde edilen bulgular tartışılarak konu ele alınmıştır.

Anahtar kelimeler: savaş, kadın ve çocuk, göç, Suriye

\section{A Study on War, Women, Children and Immigration: The Sample of Syria}

\begin{abstract}
Since 2011, the civil war in Syria has become one of the most crucial problems in Turkey and the world's agenda. The process starting with the protests of the opposition forces claimed millions of lives and destroyed the cities in Syria by 7-8 years. In this process, many Syrians were forced to emigrate. The life of women and men, young and old, rich and poor, during this forced migration, has changed completely. On the other hand, the phenomenon of war and migration dated back to old times as old as humanity, and are unknown when it first started. These two crucial issues are already discussed in the academic, political and social fields for centuries, altered to one of the main agenda items of many countries with the Syrian civil war. Recently, it is possible to read about the Syrian civil war almost every day throughout all kind of media. The subhuman cases and situations can be seen as one of the most crucial problems, in particular, of Turkey, especially for women and children. Millions of Syrian women and children immigrants have taken refuge in Turkey both as registered and unregistered, and this caused to tackle the problem in the perspective of both Turkish and Syrian citizens mandatory. To present and discuss the research findings on Syrian immigrant women and children within the scope of migration and war is the aim of this study. Within this context, after the concepts and topics in literature touched briefly on this subject, the findings examined in detailly in this study.
\end{abstract}

Keywords: war, women and children, migration, Syria

${ }^{1}$ Hatay Mustafa Kemal Üniversitesi, İletişim Fakültesi, mehmetkaranfiloglu@mku.edu.tr 


\section{GíRiş}

Savaş hem bölgesel hem de küresel çapta bir sorun olarak görülmektedir. Giderek dijital ortamların dünyayı ele geçirmesi bizi birbirimize daha da yakınlaştırmakta ancak bu durum insanlar arasındaki etkileşimi hiç olmadığı kadar da artırmaktadır. Günümüzde dünyanın neresinde olursa olsun, var olan bir savaş çoğu zaman domino etkisi göstererek tüm dünyayı etkileyen ve saran bir sorun haline dönüşebilmektedir. I. ve II. Dünya savaşları, insanlığın pek çok anlamda bugünkü kadar etkileşmediği bir ortamda gerçekleştiğinden hem günümüzde hem de gelecekte çok daha büyük yıkımları olan benzeri savaşların yaşanması olası görülmektedir.

Böylesine hassas bir ortamda savaş, ülkelerin birbirine karşı sorumluluklarını da daha da artırmaktadır. Yanı başımızda yaşanan Suriye iç savaşı ile bu duruma verilebilecek en güzel örneklerdendir. Halen devam eden iç savaş koşulları hem Suriyelileri hem de gittikleri ülkelerdeki toplumu derinden etkilemektedir.

Suriye savaşı ve beraberinde gelen iç göç; özellikle kadın ve çocuk üzerinde çok etkili olmaktadır. Birçok kadın ve çocuk, insani olmayan şartlarda göçe zorlandı veya göç etmeyi tercih etti/ettirildi. Bu zorunlu göç hem gidilen ülkeyi/ülkeleri hem de -kıyasla- Suriyeli kadın ve çocukları toplumsal, ekonomik, siyasi ve sosyo-kültürel açıdan etkilemiştir.

Bunlara yönelik olarak birçok önlem alınmakta ve çalışmalar yapılmaktadır. Ancak her yerde olduğu üzere yasalar -mevcut olmasına rağmen- çoğunlukla görmezlikten gelinebilmektedir. "Toplumsal cinsiyet eşit(siz)liği sicilleriyle övünen ülkelerde bile cinsel taciz ve istismarın işyerlerinde, kamusal alanlarda ve evlerde varlığını sürdürdügünü bilinmektedir" (Guterres, 2018). Bu ve benzeri birçok açıdan yaşanan olumsuz durumlar hem kadını hem de çocuğu olumsuz yönde etkilemektedir.

$\mathrm{Bu}$ çalışma ile savaş ve göç olgusu kavramsal olarak ele alınarak, kadın, çocuk ve göç konusuna değinerek; Suriye iç savaşı özelinde yapılan araştırma bulgularına yer verilerek konu derinlemesine tartışılacaktır.

\section{Kavramsal Olarak Göç}

Göç, bireyin veya toplulukların kalıcı ya da geçici olarak ikamet ettikleri yerleşim yerinden diğer bir yerleşim yerine doğru yer değiştirmesidir. İnsanlar bazen kendi istekleriyle bazen de zorunlu olarak göç etmek durumunda bırakılmıştır. Bu duruma neden olan etkenler ise doğal, ekonomik, sosyal, dini ve siyasidir (Selim, 2017). Göç olgusu kavramsal olarak insanlık tarihi kadar eski olduğundan birçok türü bulunmakta ve pek çok farklı etkenden etkilenmektedir. İlk insanlara bakıldığında yerleşik hayata geçene kadarki sürede göç bir yaşam tarzı iken, yerleşik hayata geçilmesi ile birlikle göç, zorunlu haller dahilinde yapılan bir eyleme dönüşmüştür. Çeşitli doğal olaylar; deprem, afet, baskın gibi insanı bir yerden diğerine göçe zorlayabilirken beşerî sebeplerin de göçe sebebiyet verdiği görülmektedir. Ekonomik sebepler, savaş, siyasi olaylar gibi insan kaynaklı diğer unsurlar da insanı göç etmeye zorlaşmıştır.

Canlılar içinde özel bir yeri olan insan ve insana dair olanı değerli ve anlamlı kılan, bunların bulundukları mekânla kurduğu bağdır. Göç ise, insan ile mekân arasındaki bağı zedeleyen önemli unsurlardan biridir (Ekici \& Tuncel, 2015).

Yapılan literatür taramasında göç kavramını ilk ele alan Dr. William Farr olarak görülmektedir. Farr, 1871 yılında gerçekleşen nüfus sayım sonuçlarına bakarak ortaya koyduğu göç, tesadüfi olarak gerçekleşen bir gerekçesi olmaksızın olan bir olgu olarak tanımlanmıştır (Ravenstein, 1885 \& Tobler, 2013). Farr'ın çalışmalarına karşıt olarak 1885 'te ve 1889 'da yapmış olduğu çalışmalarla göç kavramını teorik olarak ele alan Ravenstein'ın çalışmalarına rastlanmaktadır. Ravenstein da nüfus sayım sonuçlarına bakarak bir takım göç kanunları ortaya koymuştur. Daha sonraları yaşanan savaşlar, özellikle İkinci Dünya Savaşı ile birlikte göç ile ilgili yapılan çalışmalarda artış görülmüştür. Özellikle savaş sırasında yaşanan kitlesel kıyımlar ve ağır silahların siviller üzerinde de kullanılmaya başlanması, ki daha sonra birçoğu savaş suçu olarak anılacaktır, özellikle kitlesel ve zorunlu göçte artış görülmesine neden olmuştur. Dolaysıyla araştırmacılar da bu konular üzerinde yoğun olarak durmuşlardır. $\mathrm{Bu}$ dönemde göç alanında yapılan çalışmalarda hiç olmadığı kadar büyük bir artış görülmüştür. 
Birçok farklı açıdan ele alınan göç kavramı farklı sorunlar temelinde tartışılmıştır. Ana akımda, göç konusunda yapılan çalışmalarda göçmenlerin nereden ve ne zaman geldiği, göçmen sayıları, kayıtlı veya kayıtsız olma durumları gibi daha çok göçmen profili hakkında bilgilere odaklanılmıştır. Daha çok ülkeye gelen göçmenlere odaklanılarak göç edenlerin profili hakkında bilgilere odaklanan çalışmalar, göçmenlerin nerden geldiğine, geliş zamanlarına göre yaşanan yoğunluk durumlarına, geliş sebepleri, göç yolunda yaşanan zorluklara ve göçün yasal olup olmadığına bakılmıştır. Yasal ve/veya kayıtlı olmayan göçmenler üzerine yapılan çalışmalar üzerinde yoğunlaşıldığı görülmektedir.

Göç kavramı birçok çalışmada gelen göç ve giden göç şeklinde bir ayrıma tabi tutularak ele alınmış olarak görünmektedir. Yapılan çalışmalar genelde gelen göç odaklı çalışmalara yoğunlaşmaktadır. Topçuoğlu, yapmış olduğu bir taramada Google Akademik veri tabanı üzerinden 1990-2016 yılları arasında göç konulu makaleleri ele almıştır. Sonuç olarak kavramın İngilizce olarak 'immigrant /emigrant' (gelen göç ve giden göç) ayrımında ele alındığını, 1990 yılından beri yayınlanan göç konulu makaleler tarandığında ulaşılan 1.700,000 makale içinde 1.140,000'i, 'immigration' yani gelen göç kavramsallaştırması kullanılmaktadır. Giden göç kavramsallaştırmasını ise 650,000 makalede kullanılmakta (Topcuoğlu, 2016) olduğu görülmüştür.

$\mathrm{Bu}$ durum ülkelerin kendi perspektiflerinden konuyu ele almalarıyla ilişkilendirilmektedir. Her ülke kendi açısından göç konusunda çözümler üretmekte ve akademik olarak da bu bakış açısı kavram üzerindeki hâkim bakış açısı olarak görülmektedir.

Nicholas De Genova, yapmış olduğu bir çalışmada göç kavramını kayıt dış1/yasal olmayan göç ve göç imkanları çerçevesinde ele almıştır ve çalışmasında kavramın devletlerin hâkim politik bakış açıları çerçevesinde ele alındığını ortaya koymuştur. Genova'ya göre, esas olarak ele alınması gereken ülke perspektifinden kavrama yaklaşmak değil, kavramı bir olgu olarak düşünmek gerektiğidir (Genova, 2002). Dolaysıyla kavramın ele alınış biçimi itibari ile ortada bir yanlılık durumu söz konudur.

Topçuoğlu, çalışmasında kavramların belirli bir süre irdelenmeden kullanıldığında, salt olarak gelen göç verileri kabul edildiğinde, araştırmalarda yöntemsel bir yanlılık oluşmakta olduğunu iletmektedir. Yine çalışmasında benzer biçimde pek çok çalışmayı da referans vermektedir: El-Cherkeh, Stirbu, Lazararoiu ve Radu'nun 2004'teki Avrupanın büyümesi, göç ve kadın hareketliliği odaklı çalışmaları, Cameron ve Newman'ın 2008'de yayımlanan sosyal, kültürel ve siyasi perpektifte insan hareketliliği başlıklı kitapları gibi. Genel olarak insan ticareti suçunun temel nedeninin de "göç" olduğunu vurgulamaktadır. Bu nedensellik anlayışı doğrultusunda, sınırların yükseltilmesi de sorunun ilacı olarak kurgulanıp, düzensiz göç ve insan ticareti katı göç politikalarının meşrulaştırılmasında söylemsel bir araca dönüşebilmektedir (Topcuoğlu, 2016).

Göç olgusu farklı boyutları temelinde ele alınmaktadır. Bireylerin kendi rızası olup olmadığına göre bir ayrım yapıldığında, zorunlu veya gönüllü; göç faaliyetinin yasalara uygunluğu bakımından ele alındığında düzenli veya düzensiz; göçün süresi baz alındığında geçici veya sürekli; göç yolunun kapsamı ele alındığında ise ülke içi veya ülke dışı olarak sınıflandırılmaktadır.

Öte yandan göç kavramı denildiğinde insanların farklı gerekçeler ile daha konforlu bir yaşam sürmek adına bir yerden diğerine geçişi de anlaşılabilmektedir. Hatta kişilerin kendi rızası ile gerçekleşen bu göç türü daha çok iç göç şeklinde gerçekleşirken, hatırı sayılır bir oranda farklı ülkelere göç şeklinde de gerçekleşebilmektedir. Genelde bu göç türünün esas sebebi olarak ekonomik sebepler ileri sürülmektedir.

Diğer bir boyutta ele alındığın da ise göç kavramı içinde barındırdığı insan sayısına göre de ele alınabilmektedir. Kişisel göçler olabildiği gibi, kitlesel göçler de gerçekleşebilmektedir.

Literatürde göçler; yerine, oluşumlarına ve niteliklerine göre farklı türlerde ifade edilmektedir. En basit anlamda göçler iç göç ve dış göç olmak üzere iki farklı türde ele alınmaktadır. Ancak bunların dışında zorunlu göç, gönüllü göç, uluslararası göç, kitlesel göç gibi farklı türleri de mevcuttur. İnsanlığın var oluşuyla birlikte günümüze kadar gelen göç olgusu, canlılığını ve sürekliliğini halen devam ettirmektedir. Bu nedenle de araştırmacıların her dönemde ilgisini çekmeyi başarmıştır (Selim, 2017).

\section{Kadın ve Göç}

Göç konusu kadın söz konusu olduğunda genel olarak farklı perspektiflerinden ele alınsa da ana-akım araştırmaların çoğunda erkek egemen bakış açısıyla ele alındığı görülmektedir. Genelde kadının göç kavramı ele alınırken değerlendirilmesi "daha edilgen bir yapıda olduğu" varsayımı üzerinden 
değerlendirilmiştir. Kadının daha çok erkeğe bağlı olduğu düşüncesi üzerinden konunun ele alınması kadının göç sırasında ne türden bir konumda olduğunun net anlaşılamamasına sebebiyet vermiştir. $\mathrm{Bu}$ çalışmalarda kadınlar göçün bir öznesi olarak değil de nesnesi olarak ele alınmıştır. Berger'e göre kadının göç sürecinde daha olumsuz bir etkiye maruz kalması söz konusudur. Buna sebep olarak toplumsal cinsiyet eşitsizliğinden kaynaklanan sorunlar ve bakış açısı gösterilmektedir (Berger, 2004). Ancak diğer taraftan kadın ve göç konusu bağlamında bir literatür taraması yapıldığında konuğunun yoğunlukla feminist perspektiften ele alındığı görülmektedir. Feminist perspektif de ana-akım araştırmalara eleştirel bir yaklaşımla, kadını "nesne" olarak gören bakış eleştirilmekte ve kadının da bir özne olarak ele alınması gerektiği vurgulanmaktadır.

Ancak tüm bunlarla birlikte her iki yönden çalışmanın da ortak paydada toplandığı ve kadın denince göç öncesi, sırası ve sonrasında yaşanabilecek temel problemlerin; eğitim, sağlı, temel gereksinimler, istihdam, aile ilişkileri, evlilik ve üreme konusu ve psikolojik durumlar üzerinde yoğunlaştı̆g 1 görülmektedir. Dolayısıyla çalışmanın bu bölümünde öncelikle kadın ve göç kapsamında yoğunlukla ele alınan feminist yaklaşım konusuna yer verilerek diğer problemlere yönelik bulgular da paylaşılacaktır.

\section{Göç Eden Kadınlar ve Feminist Yaklaşım}

Belirtildiği üzere kadın ve göç konusu ana akım çalışmalarda ayrı bir konu olarak ele alınmamıştır. Bu çalışmalar daha çok göç kavramının diğer boyutları ve kuramları ile ilgilenmişlerdir; teorik olarak göç, göçün çekim modeli, iç göç, dış göç, gelen göç, giden göç...vb. Genel olarak bakıldığında ise göç kavramı farklı çalışma alanları tarafından farklı kuramsal boyutlarda ele alındığı görülmektedir. Uluslararası göç kuramları, göçün nedenlerini, nasıl gerçekleştiğini ve süreci açıklamayı amaçlamaktadır (Şeker \& Uçan, 2016). Uluslararası göç hem göçmen gönderen hem de göçmen alan ülkelerin sosyal, ekonomik ve demografik dinamiğinde merkezi bir rol oynuyor olsa da sosyal bilimler alanında yapılan çalışmalar bunu açıklamak için kapsamlı bir teori oluşturmak konusunda yavaş kalmışlardır. Teorik olarak yapılan açıklama çabaları; disiplinsel, bölgesel ve metodolojik sınırlamalar ile ayrıştırılmıştır (Massey, Arango, Hugo, Kouaouci, \& Pellegrino, 2005). Bu ayrıştırmalar sonucu kadın konusu göç alanın yalnızca feminist bir bakış açısı ile ele alındığında görünür hale gelmiştir. Feminist yaklaşım ise göç sürecinin toplumsal cinsiyet eşitsizliğini besleyen yapısını ön plana çıkarmaktadır (Şeker \& Uçan, 2016).

1960'lı yılların ikinci yarısından itibaren kadın konusu, feminist yaklaşımın etkisi ile ilgi duyulmaya başlanan bir konu haline gelmiştir. Daha öncesinde cinsiyet ayrımı yapılmaksızın göç konusunun ele alınışı, kadın üzerindeki durumun anlaşılmamasına yol açmıştır. Kadın daha önce de bahsedildiği üzere bu çalışmalarda edilgen olarak görülmüştür. Göçün asıl öğesi daha çok erkektir ve erkeğin sahip oldukları arasında kadın da vardır şeklinde yorumlanmıştır. Kadınların bu ve benzer şekilde ele alınmasını bazı yazarlar "cinsiyet körlüğü” olarak değerlendirmektedir (Ünlütürk-Ulutaş \& Kalfa, 2009).

Göç olgusu değerlendirilirken kadının da erkek cinsinden ayrı olarak ele alınıp incelenmesi gerektiği fikri ilk olarak uluslararası kadın konulu konferanslarda [Birleşmiş Milletler Kadınlar Üzerine Dünya Konferansı (1975, Meksika), Kadınların On Y1lı Üzerine Dünya Konferansı (Kopenhag, 1980)] dile getirilmiştir (Şeker \& Uçan, 2016).

Bazı uluslararası çalışmalarda kadın konusu göç eden kadınların gittikleri ülkede çalıştıkları iş pozisyonlarından ötürü görünür hale gelen bir etken olarak görmektedir (Bretel \& Sargent, 2008). Bretel ve Sargent çalışmalarında kadının ilk göç eden olduğunu (Bretel \& Sargent, 2008), Gülçür ve İlkkaracan da belirli iş kollarında çalıştırılmak için özellikle tercih edildiği ve bu sayede uluslararası göç sürecinde daha görünür hale geldiği durumlar (Gülçür \& İlkkaracan, 2002) olduğunu vurgulamışlardır.

Göç eden kadınların sürecin mağduru ya da kurbanı olarak edilgen biçimde temsil edildikleri erken dönem feminist göç çalışmalarında kadınların göç ettikleri ülke ekonomisine katkılarl ve onlara yönelmiş cinsel şiddet bağlamında ele alındıkları görülür. Bu dönem çalışmalarında kadınlar ev sahibi toplum için yarattıkları sorunlar odağında incelenerek geleneksel değerlerin taşıyıcısı, koruyucusu olmaları vasfiyla kültürel uyum sürecini geciktiren stereotiplere dönüşü̈rülmüşlerdir. Kamusal yaşamda ezilen erkeğin

Muhakeme Dergisi/Journal 2(1): 99-124, 2019 
tahakkümü altında yaşamak zorunda kalan özel alana hapsolmuş nesneler haline dönüşmüşlerdir. 1980’lerden itibaren literatürde ilgi, göç eden kadınların benzer deneyimleri, hedef ülkenin işgücü piyasasındaki işlevleri gibi başlıklara yönelmiştir. 90'lardan itibaren kadının, göç sürecinin "mă̆duru” şeklinde kodlanan pasif konumundan "değişimin faili" olarak tanımlandĭ̆ aktör konumuna doğru kaydığ görülür. Aynı zamanda göç edenlerin toplumsal cinsiyete dayalı eşitsizlik ve şiddetten korunması gerektiği ve bu amaçla uluslararası göç hukukunun düzenlenmesi gerektiği fikri de ön plana çıkmıştır. Son dönem çalışmalar kadının gelişmiş ülkelerin -örneğin bakım hizmetleri için- artan kadın işgücü ihtiyacı ya da insan ticareti gibi nedenlerle göçün öznesi haline geldiğini göstermektedir (Şeker \& Uçan, 2016).

Göç ve kadın konusunda yapılan feminist çalışmalar göç araştırmalarının eril bakış açısında etkili olmuşlardır. Sema Buz, çalışmasında sığınan ve sığınmacı kadınların göçünün kadınların kendi adlarına yola çıktıklarını, aktif olduklarını ve bağımsız bir göç süreci şeklinde yaşandığı belirtmektedir. Öte yandan kadınların, göçü, erkek temelli kurumsallaşmış şiddet ya da toplumsal cinsiyetlerinden kaynaklanan nedenlerden kaçmak için "bir baş etme" stratejisi olarak kullandıklarını iletmektedir (Buz, 2007). Buz, diğer bir çalışmasında kentleşme ile birlikte iç-göçün artış gösterdiğini, bu göç kararlarının verilişinde kadının etkin rol oynayamadığını dile getirmektedir. Bir tür, kadının edilgen bir şekilde erkek tarafından alınan göç kararana zorunlu olarak dahil olduğunu dile getirmektedir. Buz'a göre kentleşme ve iç göçle ilgili çalışmalar kadınların göçle daha dezavantajlı hale geldiklerini, toplumsal cinsiyet rollerinin arttığını, ancak gittikleri kentte bütünleşmeye büyük katkıları olduğunu göstermektedir (Buz, 2009). Diğer taraftan Ünlütürk-Ulutaş ve Kalfa çalışmalarında göç sürecinde kadınların yaşadığı mağduriyet ve zorunda kalma halinin göç sürecini kadınlaştırdığı iletmektedirler. $\mathrm{Bu}$ çalışmaya göre göçmen kadınlar ev içi hizmetlerinde ve fuhuş sektöründe artan bir şekilde yer almaya başlamışlardır. Göçmenlik ve kadınlık statülerine dayalı ayrımcılık, her iki sektöre içkin risklerle birleşince hedef ülkelerde son derece olumsuz çalışma ve yaşam koşulları oluşturmuştur. Bu süreçte farklı tarzda göçmen örgütlenmeleri kadınların hak taleplerini dile getirebilecekleri, dayanışabilecekleri ve güçlenebilecekleri uygun bir zemin hazırlamıştır (Ünlütürk-Ulutaş \& Kalfa, 2009).

Güneysu'ya göre ise mülteciler arasında kadınlar büyük bir çoğunluğu oluşturmaktadır. Buna rağmen başvuru ve değerlendirme süreçlerinde erkeğe bağlı bir aile üyesi olarak ele alınmakta ve performansa, kariyer ve eğitime bağlı göç süreçlerinde kadınlar ikincil bir öğe şeklinde işgücü unsuru olarak görülmektedir. $\mathrm{Bu}$ bağlamda erkeğin bulduğu firsata dahil olan edilgen bir yapıda değerlendirilmektedir (Güneysu, 2017).

Aksi yönde yapılan diğer bir çalışmada ise kadın üzerine yapılan çalışmaların gereğinden fazla kadına odaklandığını, cinsiyet ayrımı yapılmaksızın konunun ele alınması gerektiği vurgulamaktadır (Mahler \& Pessar, 2006). Göçmen kadınlar, göç ettikleri ülkelerde ekonomik özgürlüklerini kazandıkları zaman daha fazla kişisel özgürlük sahibi olmaktalar ve bu durum, göçün kadınlar adına olumlu bir kazanım olabileceğini gündeme getirmektedir (Mahler \& Pessar, 2006 akt: Doğanay, Şahin, \& Özdemir, 2007). Doğanay, Şahin ve Özdemir'e göre ise bu durum, göçmen kadınların yalnızca daha iyi çalışma ve yaşama koşulları elde etme peşinde koşan insanlar olarak değerlendirilmesi olarak görmektedir. Bunun yanlış olacağını savunan Doğanay, Şahin ve Özdemir göre, göç ettikleri ülkelerde kalan kadınların, kendi ülkelerine geri dönen kadınların ve tekrar bir başka ülkeye giden kadınların durumları, titizlikle incelenmeye devam edilmelidir. Feminist coğrafyacılar, bu konularda yapılan çalışmalara öncülük edecek konumdadır. Erkek nüfus göçleri konusunda birçok çalışma yapılmıştır ve kadınların göç deneyimleri konusunda yapılan çalışmaları da çoğalmaktadır. Göçmen erkekler gibi, göçmen kadınların da gittikleri ülkelerdeki yaşamlarının bir gerçeği olan sorunlara katlanmaları yanında, insan kaçakçılığı yapan kişilerin ellerine düşmelerinin istenmeyen sonuçlarını da gösteren bu çalışmalar bütün dünyada uygulanabilir bir göçmen politikası oluşturulması gereğini ortaya koymaktadır (Doğanay, Şahin, \& Özdemir, 2007).

Harding’e göre de “...kadınların göç deneyimleri, göçün tipi, göç edenin sosyoekonomik statüsü ve aile yapısı, geride bırakılan mekân ile tanışılan mekânlardaki kültür, sosyal ve ekonomik yapı gibi birçok etkene bağlı olarak farklılaşmakta ve çeşitlenmektedir. Dolayısıyla benzer şekilde göç eden kadınlarda bile belirli bir homojenlik varsayımından yola çıkmanın sağlıklı sonuçlara varılmasını engelleyebileceğini” (Harding, 1996) önemle vurgulamaktadır.

Muhakeme Dergisi/Journal 2(1): 99-124, 2019 
Görüleceği üzere göç ve kadın konusu farklı bakış açıları ile ele alınmakta ve kadın yapılan birçok araştırma sonucu, özellikle feminist yaklaşımlarla yapılan çalışmalarda edilgen bir öğe olarak ele alınmasının temel sorun olarak olduğu, gereken önemin ana akım araştırmalarda verilmediği ve erkek egemen bakış açısının kadın konusunu yeterince araştırılmadığı üzerinde yoğunlaşmaktadır. Diğer taraftan aksini savunan çalışmalar da kadın konusunun erkekten bağımsız olarak değerlendirilmesinin göç olgusunun anlaşılmasında temel etken olmadığını belirtmektedir. Her iki bakış da kadına getirdiği farklı yorumlamalara rağmen kadın konusunun ele alınması gereken önemli bir unsur olduğu ve göç sürecinde erkekten farklı olarak, eril veya feminist bir yaklaşımla değerlendirilebilecek önemli bir konu olduğunu göstermektedir.

\section{Göç Eden Kadınlar ve Ĕgitim}

Göç eden kadınların en sık zorlandığı konuların başında eğitim gelmektedir. Eğitim konusu göç edilen bölgenin dilini bilmeme, geleneksel aile yaşantısından kaynaklanan ödevlerin eğitimin önüne geçmesi, yoksulluk gibi engellere takılabilmektedir. Yahut devam eden bir eğitim durumları olması halinde ise gidilen bölgede çeşitli sebeplerden bu durum askıya alınabilmektedir.

Suriyeli göçmen kadınlar incelendiğinde göç eden kadınların 5'te birine yakını hiç eğitim almamış, yine yakın bir orandaki kadının ilkokul tamamlamadığı ancak bu kadınların yüzde 33 kadarının ilk okul mezunu olduğu görülmektedir. Lisans ve lisansüstü eğitimini tamamlayanların ise yalnızca yüzde 5 civarında olduğu aktarılmaktadır (Balcılar, 2016). Şen ve Vural'ın 2014'te yapmış oldukları çalışmada ise ülkelerini terk eden nüfusun yüzde 75 'inin kadınlar ve çocuklardan oluştuğu iletmektedir (Şen \& Vural, 2014). Yaptıkları anket çalışmasında Suriyelilerin yüzde 60'nı bekarların, bu sayının da yüzde 46'sının kadınlardan oluştuğunu belirtmektedir. "Kadınların çoğu ilkokul mezunu ve ev kadınıdır. Üniversite mezunlarl ise genellikle ögretmenlik yaparken ikinci sirayı yine ev kadınlı̆̆ almaktadır. Kadınlar, imkân tanınırsa genellikle toplumda kadına biçilen roller çerçevesinde terzilik, temizlik, tarım vb. işler yapmak istiyorlar. Türkiye'de Suriyeli kadınların sadece yüzde 2'si aktif olarak çalışmaktadır. Ihtiyaçlar açısından araştırma bulgularına bakıldığında, çocuk bezi ve kadınlara yönelik özel ihtiyaçlara ulaşmakta kamp içi ve kamp dışında önemli farklılıklara rastlanmaktadır" (Şen \& Vural, 2014, s. 1).

\section{Göç Eden Kadınlar, Săglık ve Üreme}

Suriyeli kadınlar ele alındığında diğer bir önemli husus ise evlenme ve doğuma yönelik verilerden gelen bilgilerle şekillenmektedir. AFAD verilerine göre, bugüne dek Suriye ve Iraklı sığınmacıların tedavileri kapsamında 953.466 bin ameliyat gerçekleştirilmiş; 1.143 .393 yatan hasta ve 25.919.750 milyon poliklinik hizmeti verilmiştir, 224.750 bebek Türkiye' de doğmuştur (AFAD, Ağustos 2017). Suriye'deki savaşın 2011-2018 aralığında düşünüldügünde neredeyse 7 yıllık uzunca bir süreyi kapsadığı düşünülürse, bu süre içinde yapılan evlilikler, doğumlar da çarpıcı sonuçlar ortaya koymaktadır. Şimşek ve diğerlerinin 2017'de yayınlanan yaptıkları çalışmada 2015 yılında Şanlıurfa'da yer alan Suriyeli 15-49 yaş aralığında evli kadın mültecilerin üreme, beslenme, akıl sağlığı ve cinsel yola bulaşan hastalıklar konularındaki öz değerlendirmelerine yer vermişlerdir. 458 katılımc1 ile yapılan görüşmeler sonucu; yüzde 51,3 oranında kadın yaşın altında evlendiği, yüzde 16 oranında kadının hamile olduğu, yüzde 26,7 oranında kadının prenatal (doğum öncesi) kontrolü yapmadıkları, yüzde 47,7 daha önce düşük yaptığını belirtmişlerdir. Yüzde 50,8'inde cinsel yolla bulaşan hastalık bulgusu tespit edilmiştir. Cinsel olarak aktif olan yüzde 37,8'inin doğum kontrolü yöntemlerini kullanmadığı tespit edilmiştir. Yaklaşık yüzde 90 kadının ise psikolojik olarak (sosyal destek, dil problemi, b12 gibi vitamin eksikliğinden kaynaklanan sorunlar) desteğe ihtiyaç duyduğunu belirtmiştir (Şimşek, Doni, Hilali, \& Yildirimkaya, 2017).

Göç eden kadınların en önemli sorunlarından bir tanesi de üreme konusu olarak görülmektedir. Literatürde göç eden kadınların travma yaşayabildikleri ve kadın sorunlarının başında üreme sağlığı riskleri olduğu ifade edilmektedir. Bu riskler arasında enfeksiyonel bir takım hastalıklar, gebelik öncesi, sırası ve sonrasında yaşanabilen problemler yer alırken aynı zamanda psikolojik rahatsızlıklar, şiddet, istismar ve sağlık hizmetlerine erişme imkanının bulunmayışı da üreme konusunu önemli hale getirmektedir (Yağmur ve Aytekin, 2018).

Muhakeme Dergisi/Journal 2(1): 99-124, 2019 
Birçok kadın göç edilen bölgede doğum yapmak zorunda kalmakta ya da sağlıksız koşullar içinde gebeliklerini geçirebilmektedir. Yapılan bir araştırmada göç eden kadınlarda göç edilen bölgede kadınların gebelik sırasında gerekli bakımlarını yapamadıkları, sağlık hizmetlerinden yararlanarak doğum yapabilen kadınların az miktarda olduğu ve benzer şekilde doğum sonrası da gerekli işlemlerin tam anlamıyla yapılmadığı tespit edilmiştir (Islam \& Gagnon, 2016). Bu durumun önemli sonuçlarından biri de doğum öncesi, sırası ve sonrasında hem anne hem de bebek tarafindan yaşanabilecek çeşitli hastalıkların ve ölüm riskinin artmasıdır. Diğer bir husus da özellikle sağlık hizmetlerinden yararlanamayan kadınların kayıt dışı doğum yapması, çeşitli enfeksiyonel hastalıkların ve bulaşıcı hastalıkların hem anne ve bebek hem de içinde yaşanılan toplum açısından takip edilememesi ve kontrolsüz bir şekilde gerçekleşebilmesine sebebiyet vermektedir. Yapılan bir diğer araştırmada 370 kadar kadınla görüşülmüş ve bunların en az bir kez doğum yapanlarının oranı yüzde 90 civarında olduğu görülmüştür. Bu durumun evlilik yaşı ve eğitim durumuyla da ilişkisi olduğu ortaya konmuştur (Kalkan, ve diğerleri, 2014). Özellikle doğum kontrol ve korunma yöntemlerini çeşitli dinsel ve geleneksek sebeplerle reddedebilen kadın ve aile yakınlarının da olması kadınların üreme konusunda da sıkıntılar yaşayabilmesine neden olmaktadır. Başka bir araştırmada görüşülen kadınların yüzde 82'si aile planlaması yöntemi kullanmadıklarını ifade etmiştir (Kalkan, ve diğerleri, 2014).

Üreme konusundaki en önemli başlılar arasında da kadınlara yönelik hem şiddet hem de istismar durumlarının yaşanması yer almaktadır. Bazı kadınların göç ettikleri bölgelerde cinsel, fiziksel, ekonomik vb. şiddet türlerine maruz kalması riskli bir takım davranışlarını da beraberinde getirmektedir. Türkiye'ye göç eden kadınlar arasında yapılan bir araştırmada kadınların yüzde 8'inin cinsel istismar yaşadığı tespit edilmiştir (MAZLUMDER, 2014). Bu durum kadın psikoloji üzerinde travmatik yaralar açmakta, zor kullanılan durumlarda kadınların susturularak bu durumu kabullenmeleri ve sessiz kalmaları beklenmektedir. Pek çok kadının buna yönelik olarak yapılan bir araştırmada "çaresiz" olduklarını beyan etmişlerdir (Krause, ve diğerleri, 2015).

Yağmur ve Aytekin'e göre ise göç eden kadınların üreme sağlığını etkileyen faktörler; psiko-sosyal, kültürel, ekonomik ve mültecilere yönelik tutum ve davranışlar şeklinde sıralanmaktadır. Öte yandan yapmış oldukları çalışmada göç eden kadınların yaşadığı üreme sağlığı sorunlarını ise şu şekilde sıralamışlardır (Yağmur \& Aytekin, 2018):

- $\quad$ Gebelik ve doğumla ilgili sorunlar (Adölesan gebelik, sağlıssız düşük ve doğumlar, yüksek doğurganlık)

- $\quad$ Şiddet/ İstismar/İnsan ticareti

- $\quad$ Cinsel yolla bulaşan enfeksiyonlar (CYBE)

- $\quad$ Cinsel taciz-tecavüz, şiddet ve yoksulluğa bağlı psikolojik sorunlar ve üreme sağlığına etkisi

- $\quad$ Üreme Sağlığı Hizmetlerine Erişim Yetersizliği

\section{Göç Eden Kadınlar ve İstihdam}

Göç eden kadınlara yönelik çalışmalar incelendiğinde önemli diğer bir husus olarak da kadın işgücü ve/veya istihdam konusu görülmektedir. Göçmen kadınların göç ettikleri bölgelerde çeşitli iş kollarında görev aldıkları veya almaya zorlandıkları bilinmektedir. Çocuk bakımı, ev işlerinin yanı sıra hizmet sektörü ve kas gücüne dayalı olan veya olmayan endüstriyel alanlarda kayıtlı veya kayıtsız olarak çalışabilmektedirler. Ancak kadınların pek çoğu da toplumsal cinsiyet rollerine dayalı olarak seks işçiliğine zorlanabilmekte veya diğer iş kollarında ucuz işgücü olarak da çalışmaya mecbur bırakılabilmektedir. Coşkun'a göre göçmen veya sığınmacı olarak başka bir ülkeye göç etmek durumunda kalan kadınların; bakım, ev işleri, tekstil mağazalarında satış personeli, garsonluk gibi hizmet sektörlerinde ya da imalat atölyelerinde ucuz işçiler olarak veya seks işçileri olarak kayıt dış1 işlerde çalışmaktadırlar (Coşkun, 2017). Baş ve diğerlerinin çalışması ve destekler nitelikteki Demirdezen'e ait çalışmaya göre ise göç eden kadınlar, göç eden erkeklere kıyasla daha düşük ücretli, daha düşük statülü, pek çok açıdan riskli işlerde ve istismara maruz kalarak çalışmaktadırlar (Baş, Molu, Gör, Tuna, \& Baş, 2017; Demirdezen, 2013).

Suriyeli sığınmacı kadınlara yönelik yapılan araştırmalarda Türkiye'nin çeşitli illerinde il içinde bulunan çeşitli sektörlerin, yörenin ihtiyaçlarına yönelik olarak farklı iş kollarında kadınların istihdam 
edildikleri görülmektedir. Bu durum mevsimlik olarak ihtiyaç duyulan tarım işlerinin yoğunlaştığ1 bölgelerde tarım işçiliği olarak kendini gösterirken ticaret ve sanayinin yoğunlaştığı bölgelerde ise hizmet sektörü ve/veya sanayi işçiliği olarak göstermektedir. Öte yandan yapılan bazı araştırmalarda toplumsal cinsiyet rollerinin etkisinde kalan pek çok kadın da ev hizmetleri, çocuk bakımı, yaşlı bakımı gibi daha emek yoğun ve vasıfsız işlerde çalışmakta olduğu görülmektedir (Kaygısı, 2017, s. 3; Toksöz, 2008, s. 92; Çetin, 2016, s. 1007; Lordoğlu \& Aslan, 2016, s. 793).

\section{Göç Eden Kadınlar, Evlilik ve Aile İlişkileri}

Göç eden kadınların karşılaştıkları diğer bir problem de özellikle demografik bilgi durumlarıyla ilgili olarak, aile ilişkilerinin olumsuz yönde etkilenebilmesidir. Göç edilen bölgede aile üyelerinden en az bir kişiyi kaybetmiş olmasından, çok genç yaşta ve/veya bekar olmasından, aile içi şiddette maruz kalmaktan, çok eşlilik yapılan bir aile yapısında olmasından kaynaklanan sorunları yaşayabilmektedir. Yapılan bir araştırmada Türkiye'de Suriyeli göçmenlerle yapılan evliliklerin yüzde 6'sının çok eşli evlilik (kuma alma/getirme) türünde gerçekleşmiş (KAMER, 2017), diğer bir araştırmada ise göç etme durumu aile birliğinin dağılmasına neden olabilmektedir (Hiott \& Grzywacz, 2008). Pek çok ülkede yasal olmasa da legal olmayan biçimlerde gerçekleştirilen yahut yasalarda geçerliliği olmayan dini ve geleneksel bir takım yöntemlerle gerçekleştirilen de denilebilecek evliliklerin özellikle kadınların zorunlu olarak ve yabancı bölgelere göç ettiği yerlerde çokça gerçekleşebildiği görülmüştür. Kilis’te yapılan bir araştırma da çok eşli evlilik yapmış 14 kadınla görüşülmüş ve bu durumun erkekler için özendirici kadınlar için ise çok zor, acılı ve yıpratıcı olduğu görülmüştür (Agcadağ-Çelik \& Vural, 2018).

\section{Göç Eden Kadınlar ve Psikolojik Durumlar}

Göç eden kadınlarda rastlanan diğer bir önemli husus da çeşitli sebeplerle kadın ruh sağlığı olumsuz yönde etkileyen psikolojik rahatsızlıkların yaşanabilmesidir. Göç edilen bölgedeki farklı yaşam biçimleri, koşulları, yeni bir kültüre karşı duyulan hassasiyet, yabancılaşma, uyum problemleri, dil engeli, yeterli düzeylerde hem sağlık yönünden hem de ekonomik olarak destek alamamak, zor çalışma koşulları, pek çok açıdan şiddete maruz kalma gibi etmenler kadın psikolojisini olumsuz yönde etkileyebilmektedir.

Tuzcu ve Ilgaz yapmış oldukları çalışmada göçmen kadınların yaşadığı sosyoekonomik sorunların daha az sağlık hizmeti ve psikiyatrik hizmetlerden yararlanma durumuna sebebiyet vermektedir. Çalışmada "bu kadınların ruh sağlığının korunması ve geliştirilmesi için yaşam şekilleri, karşılaştıkları zorluklar ve baş etme düzeylerinin toplum ruh sağlığında çalışan sağlık profesyonelleri tarafindan değerlendirilmesi önemlidir. Göçmen grupların yeni topluma uyum sağlamalarını kolaylaştırmak için dil kursları düzenlenmeli, sosyoekonomik düzeylerini güçlendirmek için iş imkânları sağlanmalı, sağlık hizmetlerinden yararlanmaları kolaylaştırılmalı, sağlık ve hastalıkta etkili olan kültürel faktörleri değerlendirilmelidir" denilmektedir (Tuzcu \& Ilgaz, 2015, s. 64).

\section{Çocuk ve Göç}

Literatürde çocuk konusu kadın konusunda olduğu üzere farklı perspektiflerden ele alınmakta ve değerlendirilmektedir. Genel olarak incelendiğinde çocuklar ve göç dendiğinde çocuk hakları, çocukların eğitimi, işçi çocuklar konusu ve sorunları, çocuk ve sağlık konuları, çocuk ve psikoloji konuları gibi yönlerden konunun ele alındığı görülmektedir.

Çocuk kavramı göç söz konusu olduğunda pek çok dikkat çekici istatistiki verilere dayandırılarak verilmektedir. UNICEF verilerine göre 2005 ve 2015 yılları arasında dünya geneli göç eden çocuk sayısı iki katından bile daha fazla bir oranda artarak 4 milyondan 9 milyona çıkmıştır. Öte yandan göç eden çocukların diğer çocuklara kıyasla 5 kat daha fazla olacak şekilde okula gitmediği, her 10 çocuktan birinin askeri çatışmaların etkili olduğu yerlerde yaşadığı ve 400 milyondan fazla çocuğun da yüksek oranlarda yoksulluk çekilen bölgelerde yaşamak zorunda kaldığı aktarılmaktadır (UNICEF, Children Uprooted, 2018). 
Avrupa komisyonu ise göç eden çocuklarla ilgili olarak yine UNICEF verilerine dayalı şu verileri paylaşmaktadır (Children In Migration, 2018):

- Dünya genelinde toplam 50 milyon çocuk göç etmiştir, bunların 20 milyonu şiddet ve güvensiz ortamlardan kaçarak göç etmek durumunda kalmıştır.

- Her 200 çocuktan biri mülteci konumundadır.

- $\quad$ Doğduğu ülke dışında yaşayan her 3 çocuktan biri mülteci statüsündedir.

- $\quad$ Mülteci nüfusunun yarısı çocuklardan oluşmaktadır.

- $\quad$ Göç eden her 8 kişiden biri çocuktur.

- $\quad$ Türkiye, dünyada en fazla mülteci sayısına sahip ülkedir.

- $\quad$ Avrupa genelinde toplamda 5,4 milyon (yüzde 7 oranında) çocuk göçmen bulunmaktadır.

- $\quad 2015$ y1lında AB'ye deniz üzerinden giden mültecilerin yüzde 31'i çocuklardan oluşmaktadır.

- $\quad 2015$ yilında AB'ye iltica başvurusunda bulunan 4 kişiden biri çocuk olmuştur.

- $\quad 2015$ yılında AB'de toplam 96 bin ebeveyni olmayan çocuk sığınma talebinde bulunmuştur.

Türkiye'ye yönelik verilere bakıldığında ise BMMYK (Birleşmiş Milletler Mülteciler Yüksek

Komiserliği) verilerine göre, Mart 2016'da ülkeye sığınan Suriyeli sığınmacıların yarısından fazlası çocuklardan oluşmakta, toplamda 1 milyon 125 bin kadar 0-14 yaş arası Suriyeli sığınmacı olduğu aktarılmaktadır (Aydın, Şahin, \& Akay, 2017, s. 9).

Göç sırasında çocukların büyüme ve gelişme evresinde olmaları, en az bir ebeveyne bağlı olarak yaşamaları, fiziksel ve bilişsel yetersizlikleri sebebiyle savunmasız olmaları gibi nedenlerle çocuklar göçten olumsuz yönde en çok etkilenen unsur olarak görülmektedir. $\mathrm{Bu}$ neden çocuk kavramının sıklıkla eğitim, yoksulluk, çocuk işçiliği, barınma, sağlık ve istismar gibi konularla ele alınmaktadır. Buradan hareketle çalışmanın bu bölümünde bu konulara yer verilecektir.

\section{Göç Eden Çocukların Ĕ̈itimi}

Eğitim, dünyanın hemen hemen her yerinde temel haklar arasında yer almaktadır. $\mathrm{Bu}$ nedenle çocukların da temel hakları arasında eğitim yer almaktadır. "Çocuk Hakları Sözleşmesi”"ne göre eğitim, madde 28 'de ilköğretim herkes için zorunlu ve parasız, eğitim ve meslek seçimine ilişkin bilgi ve rehberliği bütün çocuklar için elde edilebilir halde olması şeklinde ele alınmaktadır (BM, 1989). Dolayısıyla eğitim hakkı tüm dünyada çok önemli ve tüm çocukların doğal hakkı olarak görülmektedir, diyebiliriz. Eğitim almayan veya alamayan çocukların daha fazla şiddete maruz kaldığ 1 ve/veya şiddete meyilli oldukları belirtilmektedir. Şiddetin yanı sıra stres bozukluğu, fiziksel ve psikolojik gelişimde gerilik, toplumsal uyum sorunları gibi konularda da eğitim eksikliğinden kaynaklanan problemlerin yaşandığı belirtilmektedir. Polat'a göre, eğitim hakkından yararlanamayan çocuklar daha fazla istismar ve şiddet riskine maruz kalmaktadır (Polat, 2007).

Göç eden çocuklarda da eğitim önemli bir konu olarak görülmekte ve göçe maruz kalan çocuklarda eğitim konusunda pek çok sorunla karşılaşılabilmektedir. Öncelikle göç edilen bölgenin veya ülkenin dili göç eden çocuklar tarafından bilinmiyor ise yahut göç edilen ülkede verilen eğitim dili çocuk tarafından bilinmeyen bir dil ise çocuğun eğitiminde aksamalar yaşanabilmektedir. Türkiye'ye göç eden Suriyeli sığınmacı çocukların ancak yüzde 10'u eğitim alabilmiştir (Sayılarla-DünyaÇocuklarının-Durumu, 2014). Türkiye'deki Suriyeli sığınmacı çocukların 968 bini okul çağında ancak MEB (Millî Eğitim Bakanlığı) verilerine göre bu sayının 325 bini okullarda kayıtlı durumdadır (Erdoğan, 2017; UNICEF, 2016). UNICEF verilerine göre; Türkiye, Lübnan, Ürdün, Irak ve Mısır'a göç eden çocukların yüzde 43'ü okula gitmemektedir. Eğitime dahil olmama ve/veya olamama nedenleri arasında başvuru sırasında bir takım evrakların eksik olması, okula ulaşım imkanının yoksunluğu, güvendik endişeleri, çocuk işçiliği ve çocuk evlilikleri gösterilmektedir (UNICEF, 2018).

Göç edilen ülkede eğitime tabii tutulan çocukların psiko-sosyal gelişimleri, uyum sorunlarının çözümü, göç sırasında yaşanan travmatik durumların analiz edilebilmesi ve tedavi edilebilmesi gibi durumlar takip edilebilir olmaktadır. Eğitime dahil edilemeyen veya edilmeyen çocukların ise pek çok uyum sorunlarının yanı sıra göç edilen ülkede istismar edilme ve/veya suça işleme, suça karışma gibi eylemleri gerçekleştirme ve bu eylemlere maruz kalma riski artmaktadır. Göç edilen ülkede uyum sürecindeki çocukların davranış problemleri, düşük benlik saygısı ve öz düzenleme becerileri ortaya çıkabilmektedir (Hodes, 2000). Gümüşten'e göre, çok kültürlülüğün önemli olduğu, bunun anlaş1lması 
ve kabul edilmesinin göç eden çocukların benlik saygısı düzeylerinde, akademik başarı düzeylerinde artış, duygusal ve davranışsal problemlerinde azalma şeklide etki edeceğini belirtilmektedir (Gümüşten, 2017, s. 258).

\section{Göç Eden Çocuklar ve Yoksulluk}

Yoksulluk denildiğinde genellikle kişi başına düşen milli gelir, aylık elde edilen kazancın hane halkı sayısına bölünmesi gibi ekonomik sonuçlar anlaşılmaktadır. Ancak yoksulluk genel olarak pek çok şeyden yoksun olma olarak da ele alınabilmektedir. Genel kanıdan hareketle yoksulluk ile ilgili yapılan çalışmalarda uluslararası veya ulusal bir takım istatistiklere rastlamak mümkündür. Dünya bankası “uluslararası yoksulluk sınırı"nı günlük kişi başı 1 Amerikan Doları olarak ifade etmektedir. Bu sınırda yaşanan yoksulluk durumuna "gelir yoksulluğu" adı verilmektedir. Ancak su, beslenme, eğitim vb. ihtiyaçların karşılanamaması durumuna da "temel gelir yoksulluğu" denilmektedir. Öte yandan birey tüm gelirini harcamasına rağmen temel besinini yeterince temin edemediği durumda ise "ağır yoksulluk" durumu yaşanmaktadır, denilmektedir (UNICEF, 2000).

Çocuk yoksulluğu denildiğinde ise farklı görüşler bulunmakla birlikte genellikle çocukların temel hak ve ihtiyaçları için belirli bir gelir durumunun altında yaşamak zorunda kalması ifade edilmektedir. Özellikle belirli yaş grubu çocukların gelir elde etme durumunun olmayışı, hane halkında düşen gelirinin azalması ve anne ve bebeğin çaresiz kalması durumuna sebebiyet verebilmektedir. Buna yönelik olarak UNICEF, çocuk yoksulluğunu; bebek ve çocuk ölümleri, temiz içme suyuna erişim imkânı, temizlik ve bakım yapabilme durumları, sağlık koşulları bakımından uygun koşullara sahip olma miktarı, çocuk ve bebek ölüm verileri, eğitim durumları gibi oranlar üzerinden açıklamaktadır (UNICEF, 2002).

Bu bilgiler 1şı̆̆ında incelendiğinde özellikle göç eden çocuklarla ilgili olarak; göç durumunda pek çok ailenin yoksullaştığı ve yerleşilen yerde iş bulamama, yasal engellere takılma, özellikle göç edilen bölgede dışlanma, ekonomik şiddete maruz kalma gibi etmenlerle pek çok temel hak ve gereksinimlerinden mahrum kaldıkları aktarılmaktadır (Avşar-Kurnaz, 2007). UNICEF 2016 verilerine göre; dünyada 385 milyon çocuk ağır yoksulluk koşullarında yaşamaktadır (UNICEF, 2016). Öte yandan 2018 verilerine göre Ürdün'de yapılan bir araştırmada Suriyeli mülteci çocukların yüzde 85 'inin yoksulluk sınırının altında yaşadığını, BM'nin Suriyeli ailelerin çocuklarının beslenme, eğitim ve korunma gibi temel ihtiyaçlara gereksinim duyduğunu, Suriyeli çocukların yüzde 94'ü beş yaşın altında ve eğitim, sağlık, su ve sanitasyon, çocuk koruması ve güvenliği gibi temel gereksinimler arasında gösterilen en az iki boyuttan mahrum olarak "çok boyutlu (multidimensional) yoksulluk" yaşadığını ve son olarak Ürdün'deki her Suriyeli dört aileden birinin gıda problemi yaşadığını belirtilmektedir (2018).

\section{Göç Eden Çocuklar ve Çocuk İşçiliği}

Çocuk işçiliği genellikle ekonomik olarak elverişsiz koşullarda yaşamak zorunda kalan çocukların karşılaştığı bir durum olarak karşımıza çıkmaktadır. Çocuklar beslenme, barınma, sağlık ve eğitim gibi temel gereksinimleri karşılanamadığ kullanılarak çalıştırılmak suretiyle sorun yaşayabilmektedir. Özellikle göç eden çocukların ailelerinin yaşadığı olumsuz koşullar veya çocukların ailelerini kaybetmeleri durumunda çocuk işçi olarak çalıştırılması durumu da söz konusu olabilmektedir. Kaynaklarda çocukların genel olarak inşaat, tekstil, hizmet, tarım ve diğer zirai faaliyet gösteren sektörlerde çalıştırıldığı yazmaktadır.

ILO verilerine göre; dünya genelinde 218 milyon 5-17 yaş aralığındaki çocuk işçi bulunmakta, 152 milyonu çocuk işçiliğin kurbanı olarak kayıtlı bulunmakta, 73 milyonu ise tehlikeli sayılabilecek iş kollarında çalışmaktadır. Çocukların yüzde 71'i tarım ve ziraat sektöründe, yüzde 17'si hizmet sektöründe, yüzde 12 endüstriyel alanda çalışmaktadır (ILO, 2017).

Göç eden çocukların da çocuk işçiliğine dahil olma riski artmaktadır. Örneğin Suriyeli göç eden çocukların göç ettikleri ülkelerde çalışmak zorunda kalmaları, eğitime dahil olamamaları ve/veya olmamaları şekilde sonuçlanmaktadır. Öte yandan ailesi ile birlikte göç eden çocukların ekonomik yetersizlikler sebebiyle çalışmaya zorlandıkları ve/veya yönlendirildikleri ortaya çıkmıştır. Lordoğlu ve Aslan'ın yapmış oldukları çalışmada Suriyeli göçmen ailelerin ekonomik yetersizlikler sebebiyle 
çocuklarını çalıştırdıklarını belirtmişlerdir. Dahası bazı çalışan çocukların da ödemelerini almakta zorluk yaşadıklarını, normal çalışma ücretlerine kıyasla çok daha düşük ücretlere çalışmaya zorlandıkları ve çeşitli gerekçelerle ücretlerinden kesinti yapıldığını belirtmişlerdir (Lordoğlu \& Aslan, 2018).

\section{Göç Eden Çocuklar ve Săğlk}

Göç eden çocuklarla ilgili olarak özellikle sağlık konusu önemli olarak görülen bir konu olarak görülmektedir. Yapılan pek çok çalışma göç eden çocuklara yönelik olarak sağlık verilerini ortaya koymaktadır. Dünya Sağlık Örgütü'ne göre; Ürdün, Lübnan, Irak ve Türkiye'de bulunan Suriyeli sığınmacı çocukların kızamık, verem, deri hastalıklarına yakalandıkları belirtilmektedir (ORSAM, 2015; Korkmaz, 2014). Öte yandan göç eden çocuklarda beslenme bozuklukları, dehidrasyon, su ile bulaşan hastalıklar, oral yol ile bulaşan hastalıklar, hava yolu ile bulaşan hastalıklar, paraziter hastalıklar gibi çeşitli türden sağlık probleminin oluşması olası görülmektedir. "Yetersiz tarama programları sonucu diyabet, hipertansiyon, kanser vb. kronik hastalıklarda artış, yetersiz doğum öncesi bakım sonucu büyüme ve gelişme gerilikleri, anne ölümleri artışı, kronik beslenme yetersizlikleri, iyot yetersizliği, D vitamini yetersizliği, cinsel yolla bulaşan hastalıklarda artış, ruh sağlığı sorunları, alkol ve madde bağımlılı̆̆ bu sağlık sorunları arasında yer almaktadır" (İlhan, ve diğerleri, 2016'den akt: Kara \& Nazik, 2018, s. 61).

Sağlık konusu ile ilgili göç eden çocuklara yönelik diğer bir önemli husus da göç edilen bölgedeki sağlık hizmetlerinin durumu, gidilen bölgedeki dilin bilinmemesi, ekonomik yetersizlikler, sağlik koruma programlarından yoksunluk, ulaşım problemleri ve diğer stres kaynakları ile ilgilidir. Yapılan bir araştırmada göç eden çocukların "beslenme, barınma, hijyen sorunları ve psiko-sosyal" sorunlarının olduğu aktarılmaktadır (Geçkil, Aldem, \& Kaleci, 2017, s. 176).

\section{Göç Eden Çocuklara Yönelik İstismart}

Çocukların bir ayrım yapılmaksızın çeşitli yönlerden istismar edilmesi maalesef ki hemen hemen her ülkede yaşanan bir durumdur. Bu durum karşısında pek çok yasal yaptırım bulunmasına karşın bu konuda yaşanan pek çok olumsuz durumun da yaşandığı bilinmektedir. Çocuk istismarı denildiğinde genellikle çocukların cinsel yönden istismar edilmesi genel olarak işlenmiş olsa da aslında bir çocuğun fiziksel ve/veya psikolojik gelişimini olumsuz yönde etkileyen davranışların tümü olarak ele alınmaktadır. Dolayısıyla yalnızca bir çocuğun cinsel yönden istismar edilmesi değil, aynı zamanda okula gönderilmemesi, her türlü şiddete maruz kalması, beslenme güçlüğü yaşaması, travmatik sonuçları olabilecek türden çatışmaların ortasında bırakılmaları, bakım ve sağlık haklarından yeterince yararlanamamaları, işçiliğe zorlanmaları gibi sorunlar da çocuk istismarı kapsamında ele alınabilmektedir.

Yapılan pek çok çalışmada göç eden çocukların, özellikle dış göç yapmak zorunda kalan çocuklar, göç öncesinde, sırasında ve sonrasında yaşadıkları travmatik olaylar neticesinde ruh sağlıklarının olumsuz yönde etkilendiği görülmüştür. Buna paralel olarak da ihmal ve istismara uğradıkları görülmüştür. Örneğin; savaştan kaçan pek çok Suriyeli sığınmacı çocuğun, özellikle kız çocuklarının, küçük yaşta evliliğe maruz bırakılması buna verilebilecek örnekler arasındadır.

Dünya sağlık örgütüne göre 19 yaş altı yapılan bütün doğumlar adölesan doğrum olarak kabul edilmektedir. Nüfus ve Vatandaşlık İşleri Genel Müdürlügü’nden alınan verilere göre (bkz: Tablo 2), erken yaşta (adölesan) doğum oranında da artış gözlemlenmektedir. Türkiye geneli yapılan doğumların 2016 yılında toplam sayısı 1.309.771 olarak gerçekleşmiştir. Bunlardan 75.499 tanesi erken yaşta doğum olarak yani 19 yaş altı çocukların yaptığı doğumlardan oluşmaktadır. Bu yaklaşık olarak yüzde 6 gibi bir orana tekabül etmektedir. Sayısal olarak düşük görünebilen bu rakam temelinde bir çocuk hayatını barındırdığından 1 sayısı bile bu tür verilerde büyük önem taşımaktadır. 
İstatistiki Bölge Birimleri Sınıflaması ve Annenin Yaş Grubuna Göre Doğumlar, 2016

Annenin yaş grubu

\begin{tabular}{llllllll} 
Yıl & & Toplam & & & & & \\
& IBBS & & $<15$ & $15-17$ & $18-19$ & $20-24$ & $25-29$ \\
\hline 2016 & & & & & & & \\
& & & & & & & \\
& $\begin{array}{l}\text { TR } \\
\text { Türkiye }\end{array}$ & $\mathbf{1 3 0 9 7 7 1}$ & $\mathbf{2 3 4}$ & $\mathbf{1 6 3 9 6}$ & $\mathbf{5 8 ~ 8 6 9}$ & $\mathbf{3 0 8} \mathbf{3 0 6}$ & $\mathbf{4 0 5} \mathbf{5 8 5}$
\end{tabular}

$\underline{\text { Annenin yaş grubu }}$

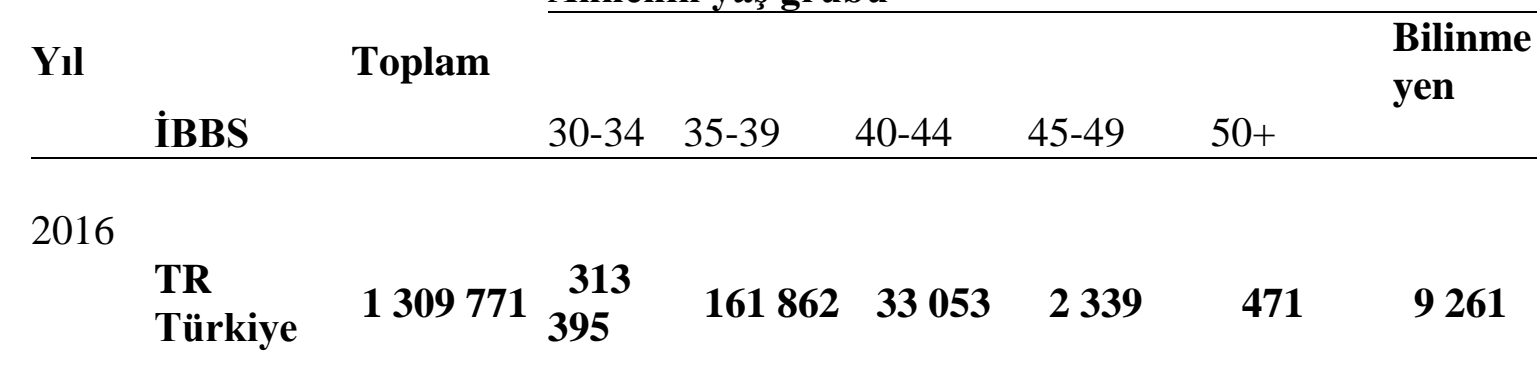

Kaynak: Nüfus ve Vatandaşlık İşleri Genel Müdürlüğü, 2016.

Diğer taraftan çocuk yaşta evliliklerinin de sayılarındaki büyüklük göze çarpmaktadır. 2015'te yapılan 16-17 kız çocuğu evlendirmeleri sayısı 31.337 iken bu sayı 2016 yılında gerileyerek 27.637 olarak gerçekleşmiştir (bkz: Tablo 2). Bu süreçteki temek etkenlerden biri artan Suriyeli göçmen sayısı ve kayıt dışı doğumların Suriyeler tarafından daha çok gerçekleştirilmesi. Sayılar bir önceki yıla göre düşüşte görünse de aslında bu kayıt altına alınamayan, hastane yerine geleneksel yöntemlerle doğum yapan gizli kadın sayısındaki artışla açıklanabilmektedir.

Tablo 2. 2015 ve 2016 Klz Çocuk Evlenme Verileri

\begin{tabular}{|c|c|c|}
\hline 2016 & $\begin{array}{l}\text { Toplam } \\
\text { evlenme } \\
\text { sayısı }\end{array}$ & $\begin{array}{c}\text { Kız çocuk } \\
\text { evlenmelerinin } \\
\text { toplam }\end{array}$ \\
\hline & & $16-17$ \\
\hline Toplam & 594493 & 27637 \\
\hline
\end{tabular}

\begin{tabular}{|c|c|c|}
\hline 2015 & $\begin{array}{l}\text { Toplam } \\
\text { evlenme } \\
\text { sayısı }\end{array}$ & $\begin{array}{ll}\text { Kız çocuk } & \begin{array}{l}\text { cocuk } \\
\text { evlenmelerinin } \\
\text { toplam }\end{array} \\
\text { Evlenen kizevlenmeler } \\
\text { çocuk sayısı içindeki oranı } \\
16-17 \quad(\%)\end{array}$ \\
\hline Toplan & $\begin{array}{l}\mathbf{6 0 2} 982 \\
2016 .\end{array}$ & 31337 \\
\hline
\end{tabular}

Muhakeme Dergisi/Journal 2(1): 99-124, 2019 


\section{“Kadın ve Çocuk" ve Zorunlu Göç Bağlamında Savaş ve Göç Eden Bireylere Yönelik Yaklaşımlar: Suriye Örneği}

Savaşın ilk ne zaman çıktığı tam olarak bilinmemektedir. Çeşitli akademik olmayan kaynaklarda tarihteki belirli savaşlar ilk olarak yazmaktadır. Birçok forum ve e-ansiklopedi görevi üstelenen sitelerde tarihte bilinen ilk savaşın Sümerler-Akadlar arasında MÖ 2700'de (E-Bilge, 2010) veya MÖ 2271 (Christian, 2012) yaşandığı ileri sürülmektedir. Britanica ve Wikipedia'da yazılana göre ise bu savaş MÖ 2334-2279 arasında yaşanmıştır (Edzard, Frye, \& Soden, 2018; Wikipedia, 2018). Öte yandan, Kurukshetra olarak da bilinen Mahabharat savaşı ${ }^{2}$ kimi kaynaklarda astrolojik hesaplamalarla MÖ 3067'ye dayandırılmaktadır (Achar, 2012). Kimi kaynaklar ise yazılı antlaşması bulunduğundan Kadeș savaşını (MÖ 1274) ilk olarak ele almaktadır (Çiftçi, 2010). Daha birçok farklı bakış açısı bulunmaktadır. Savaşı bir yaşam mücadelesi olarak ele alırsak ilk insanlardan mağara dönemine kadar devam eden insan-doğa, insan-hayvan arasında yaşananlara bile dayandırmak mümkündür yahut yazılı dönemden önce de olsa birçok hiyeroglif, mozaik ve diğer başka yöntemlerle yapılmış tasvirlerde birçok savaş türü günümüze aktarılmıştır. Dolayısıyla şunu söyleyebiliriz ki: Hangi savaşın "ilk" oluşuna yönelik bir konsensüs bulunmamaktadır. Çünkü savaşa yönelik bakış açılarının farklılaşmakta ve dolayısı ile bazı kaynaklarda savaşı bir çatışma olarak ele alan, bazısında savaşı bir şiddet yolu olarak alan çeșitli yorumlara rastlanmıştır. Dolayısıyla her bir bakış açısı farklı şekilde savaşı "ilk" olarak nitelendirmektedir. Lakin dört dinin ortak olarak ele aldığı Hz. Adem'in oğullarından Habil ve Kabil arasında yaşanan anlaşmazlık sonucu Habil'in, Kabil tarafından öldürülmesi bildiğimiz anlamda savaşın ilk formu olarak görülmektedir (Wikipedia, 2018; Gonca, 2002).

Genel olarak tanımlanacak olursa "savaş, planlanmış, belirli bir amaç uğruna yapılan girişimleri toplumsal olarak tasdiklenmiş olan ve farklı niteliklerdeki nüfusun çoğunun dâhil olduğu bir durumdur. Silahlı güçler (daha ziyade erkekler) saldırıyı gerçekleştirebilmek ve değişik şekillerde savaşa destek veren silahsızları (daha ziyade kadın, çocuk ve yaşlılar) savunabilmek için hiyerarşik olarak organize olmuştur" "Mansfield, 1982).

Savaş, birçok açıdan toplumları olumlu veya olumsuz yönde etkileyebilmektedir. Ancak her ne olumlu yönü olursa olsun, savaş insani birçok durumu göz ardı ettirebilen etmenleri barındırdığından kazanımlarından ziyade kayıpları ile ele alınmalıdır. Çünkü, bu süreçte en çok etkilenen tüm amaçlardan azade savaş ortamında kalan masum insanlar olmaktadır. Bu durum dünya kamuoyunda ses getiren birçok örneği içinde barındırmaktadır: Bodrum'dan Yunanistan'a kaçmak isterken batan bottan kurtulamayan ve sahile vuran Aylan bebek, Vietnam savaşının simgesi haline dönüşen Kim Phuc, Sovyetler Birliği ve Afganistan arasındaki savaş sırasında öksüz kalan ve sonradan "Afgan Kızı" olarak National Geography'nin kapağında ünlenen Şarbat Gula, Vitenam savaşında ABD bombardımanından kaçmak isterken nehirden geçmek zorunda kalan anne ve çocuklarının nehirdeki görüntüsü gibi.

Yalnıza bu görüntüler üzerinden bile savaşın sembol anlarında çoğunlukla konunun odağında ya çocuk ya da kadının olduğu görülmektedir. Dolayısıyla bu durum savaşı hem eril bir konuma hem de savaşın etkileneni ve mustarip olanına bakıldığında ise hafizalarda çoğunlukla kadın ve çocuk olarak imgelemekte olduğu görülmektedir (Savaş ve Siyasal Şiddette Hafiza ve Toplumsal Cinsiyet Genç Araştırmacılar Konferansı, 2014). Buradan hareketle savaşın yarattı̆̆ı olumsuz etkilerin kadın ve çocuk üzerinden biriktiği çıkarımını yapmak mümkündür.

Özellikle savaş durumunda bu masum kitlenin çeşitli sebeplerle zorunlu olarak göçe maruz kalması, bu insanlar için koşulları daha da zorlaştırmaktadır. Çünkü zorunlu göç ya aile reisinin kararı ya da ailesini kaybeden kişilerin savaş koşulların yarattığı olumsuzluklardan korunma içgüdüsü ile ülke içinde başka

\footnotetext{
${ }^{2}$ Wikipedia'da bu savaşın MÖ 400 yılında yaşandığı yazmaktadır. Kaynak: https://en.wikipedia.org/wiki/Mahabharata\#Historical context Erişim Tarihi: 21 Ocak 2018

${ }^{3}$ Cümle, Kağnıcı'nın, Ofer Zur'un “The Psychohistory of Warfare: The Co-Evolution of Culture, Psyche and Enemy” adlı çalışmasının çevirisinde kullandığı hali ile kullanılmıştır. Her iki çalışmanın kaynakça bilgileri aşağıdaki gibidir:

Ofer Zur, "The Psychohistory of Warfare: The Co-Evolution of Culture, Psyche and Enemy", Journal of Peace Research, Vol. 24, No. 2, 1987, 125-134.

Gökhan Kağnıcı, “Savaşın Psiko-Tarihi: Kültür, Ruh ve Düşmanın Birlikte Evrimi”, Tarih Okulu, Sayı: VI, 2010, 125-143.
} 
bir bölgeye; farklı bir şehre, akraba yanına...vs. veya yurtdışına mülteci, sığınmacı veya göçmen olarak yasal veya yasadışı yollarla gerçekleşmektedir. Kişilerin ekonomik durumları, göç ederken durumun elverişlilik hali, göç eden kişilerin ailevi yapıları, kültürel etmenler gibi birçok unsur, zorunlu göçten etkilenme oranını değiştirmektedir.

Zorunlu göç, gerekçesi ne olursa olsun ve göçen kitlenin ekonomik, sosyolojik ve psikolojik durumları değişkenlik gösterse bile hem gidilen yer hem de gidenler için pek çok farklı problemi beraberinde getirmektedir. 2015 yılı verilerine göre, yaklaşık 232 milyon insan yaşadıkları göç deneyimi sonrasında kendi ülkesi dışında yaşamaktadır (IOM, World Migration Report-Facts And Figures, 2015).

2010 y1lı itibariyle özellikle Afrika'nın kuzeyinde bulunan Libya, Tunus, Mısır başta olmak üzere başlayan ve sonradan Arap Baharı olarak anılan süreç tüm orta doğuyu etkisi altında bırakmıştır. Bu süreçte birçok insan başka ülkelere; sığınma kamplarına veya kaçak olarak yerleşmek zorunda kalmıştır. Birçok insan bu zorunlu göç sırasında hayatını kaybetmiş, yaşanılması arzu edilemeyen anılar bırakmıştır. Sürecin 2011 yılında Suriye'ye sıçraması, ülke içinde mevcut olan farklı yapıların birbirine savaş ilan etmesi bir iç savaşı tetiklemiş ve bu farklı unsurlar arasında halen devam etmekte olan ve komşu olan veya olmayan birçok ülkenin ve uluslararası örgütün dahil olduğu küresel bir soruna dönüşmüştür. Milyonlarca insan Suriye'den göç etmek zorunda kalmıştır. Çoğunlukla bu göçmenlerin büyük bir bölümü yaklaşık 900 km uzunluğundaki sınırı paylaşmakta olduğu Türkiye'ye göçmüştür.

15 Mart 2011 tarihi Suriye açısından değerlendirildiğinde bir dönüm noktasını ifade etmektedir. Bu tarihte Arap baharının da etkisinde BAAS iktidarına karşı muhalifler tarafından gösteriler yapılmaya başlanmıştır. Dera kentinde başlayan gösterilerde Suriye Devlet Başkanı Beşşar Esad karşıtı göstericilere güvenlik güçleri ateş açarak karşılık vermiştir. Ateş sonucu ölen 4 kişi üzerine gergin artarak devam etmiştir. Suriye'nin Ürdün sınırında yer alan kentte yaşananlar kısa sürede Cisr el Şugur ve Humus'a da sıçramıştır. Ancak gösterilerle başlayan süreç hızla yerini silahlı çatışmaya bırakmıştır. 2012'de gösteriler Halep'e, ki burası Suriye'nin en büyük şehridir, sıçrayınca ülkede iç savaş halini almıştır. 5 yıl süren çatışma da Halep yerle bir edilmiştir. 2013 yılında ise muhalif güçler Rakka'yı ele geçirerek daha sonra burayı IŞID, DAEŞ olarak bilinen (Dünya genelinde ISIS) yeni bir devletin başkenti olarak ilan etmişlerdir. Birleşmiş Milletlere göre, Şam yakınlarındaki Guta'da yaşanan kimyasal saldırı sonucu birçok sivil sarin gazından etkilenmiş ve bu durum Dünya basının da geniş yer bulmuş hatta "Guta Katliamı" olarak da anılmıştır. 2014'te yapılan seçimlerde yüzde 88 oy oranıyla Beşşar Esad tekrardan başkanlık koltuğuna oturmuştur. ABD ve AB bu seçimleri "gayri meşru" olarak ilan etmiş ve muhalif kontrolündeki bölgelerde sandık kurulmamıştır. Yine 2014'ün haziran ayında ise DAEŞ Suriye ve Irak'ın kuzeyinde ele geçirdiği topraklarda halifelik ilan etmiştir. Bu olay üzerine üç ay sonra ABD önderliğinde koalisyon güçleri hava operasyonlarında bulunmuştur. Bu ülkelerin arasına daha sonradan Rusya da dahil olmuştur. 2016 yılında ise Rusya ve Türkiye'nin devreye girmesi ile Halep'te bulunan birçok kişinin tahliyesi gerçekleştirilmiştir. Yaklaşık 25 bin kişi İdlib'e yerleştirilmiştir. İblid ise muhalif güçlerden olan Özgür Suriye Ordusuna ait bir bölgedir. Türkiye ve Rusya, Astana'da Birleşmiş Milletler'in yürüttüğü Cenevre görüşmelerinin devamı niteliğindeki müzakere sürecini başlatt1. Görüşmelerde, muhalifler ve Șam rejimi bir araya getirmiștir. 2017-2018 arasında başlayan Türkiye ve Rusya'nın Astana'da Birleşmiş milletlerin yürüttüğü Cenevre görüşmelerinin devamı niteliğindeki muhalifler ve Şam rejiminin bir arayan getiren müzakere sürecini takiben Özgür Suriye Ordusu ile yapılan operasyonlarda Cerablus daha sonra El Bab DAEŞ'in elinden, 2018 itibari ile de Afrin YPG'nin elinden alınmıştır' .

Başbakanlık Afet ve Acil Durum Yönetimi Başkanlığı'na bağlı olarak açılan Asiye Bekarca Şen ve Cem Vural'ın yapmış oldukları çalışmalarının özetinde yer alan bilgilere göre iç karışıklığın üçüncü yılında yaklaşık olarak 100.000 kişi hayatını kaybetmiştir. "1.948.746 Suriyeli vatandaş kendi ülkesini terk ederek Türkiye, Irak, Lübnan, Ürdün ve Mısır’a sı ğınmacı olarak yerleşmiştir. Ülkelerini terk eden nüfusun yüzde 75'ini kadınlar ve çocuklar oluşturmaktadır" (Şen \& Vural, 2014). Bu veriler, Suriye İnsan Hakları Gözlemevi'nin Kasım 2017 bilgilerine göre yüzde 250 oranında artarak 343 bin 511 insan şeklinde güncellenmiştir. Üstelik bu ölenlerin 102 bin 618'i sivil, 19 bini çocuk, 12 bini ise kadın

\footnotetext{
${ }^{4}$ Bu kısım NTV'nin web sitesinde yer alan haberdeki bilgilerden yararlanılarak hazırlanmıştır. Adres: https://www.ntv.com.tr/dunya/suriye-ic-savasinda-6-yilda-neler-yasandi,lkOVGc0sPUqbvDUE EDsqA Erişim Tarihi: 29 Mart 2018
}

Muhakeme Dergisi/Journal 2(1): 99-124, 2019 
olarak kaydedilmiştir (Dw.com, 2017). AFAD’1n 06.03.2018 tarihli Göç İdaresi Genel Müdürlüğü'den alınan verilerine bakılacak olursa toplamda 3.540.648 Suriyeli, Türkiye'de bulunmaktadır (AFAD, Suriye GBM Bilgi Notu, 2018). Suriye genelinde ise toplamda 6,3 milyon insan yerinden edilmiş ve 13,5 milyon insan ise "insani yardıma muhtaç" hale gelmiştir.

Suriye özelinde değerlendirildiğinde son günlerde sıkça duyduğumuz 3 kavram gündeme gelmektedir: Sığınmacı, göçmen ve mülteci. Bu üç kavram kendi ülkesinden başka bir ülkeye göç eden insanlar için belirli şartları taşımaları halinde durumlarını ifade eden tanımlamalar olarak karşımıza çıkmaktadır. Göçmen tanımı Uluslararası Göç Örgütü'ne göre, kişinin yasal statüsüne, gönüllü veya zorunlu olup olmadığına, göç etme sebeplerine, göç edilen yerdeki kalış süresine bakılmaksızın, sürekli ikamet edilen yerden çıkılarak uluslararası bir sınırda veya kendi ülkesinden başka bir ülkede bulunan kişiler göçmen olarak kabul edilmekte, şeklinde yapılmaktadır (IOM, 2018). Mülteci ise Avrupa Konsey Yönergesinin 2. Maddesinin (c) fikrasında şu şekilde ele alınmaktadır (T.C.İ.B, Şubat 2005, s. 212):

"Madde 12 kapsamına girmeyen ve irk, din, milliyet, siyasal görüs ya da belirli bir sosyal gruba üye olmak nedeniyle zulüm göreceğine dair yerinde bir korkuyla uyruğunda olduğu ülkenin dışında olan ve söz konusu korku nedeniyle kendisini o ülkenin korumasina bırakmak istemeyen bir üçüncü ülke uyruklu ya da, yukarıda belirtilen nedenlerle önceki daimi ikamet yeri olan ülkenin dışında olup da o ülkeye dönemeyen ya da, söz konusu korku nedeniyle, dönmek istemeyen vatansız bir kişi anlamına gelir"

Sığınmacı da "mülteci olarak uluslararası koruma arayan ancak statüleri henüz resmi olarak tanınmamış kişilere denir. Bu terim genellikle, mülteci statüsü almaya yönelik başvurularının hükümet ya da Birleşmiş Milletler Mülteciler Yüksek Komiserliği (BMMYK) tarafindan karara bağlanmasını bekleyen kişiler için kullanılır" (Vardar, 2018). "Suriyeliler ne göçmen tanımına ne de mülteci tanımına uymaktadır. Mevzuattaki boşluk sebebiyle Suriyelilerin statüsüyle ilgili "Yabancilar ve Uluslararası Koruma Kanunu” (YUKK) çıkarılmıştır ve Suriyelilerin statüsü "Geçici Koruma” olarak belirtilmiştir" (Çakran \& Eren, 2017, s. 7). Bu geçici koruma statüsü ile ilgili olarak YUKK'un "Geçici koruma"' başlıklı 91. Maddesinin 1. fikrası şu şekildir: “(1) Ülkesinden ayrılmaya zorlanmış, ayrıldığ ülkeye geri dönemeyen, acil ve geçici koruma bulmak amacıyla kitlesel olarak sınırlarımıza gelen veya sınırlarımızı geçen yabancılara geçici koruma sağlanabilir'” (Resmî Gazete, 2013: Md:91). Buradaki geçici ifadesiyle aslında Türkiye bir anlamda tüm bu "geçici koruma" statüsünde Suriyeli bireylerin daha sonra ülkelerine dönmelerini zorunlu koşmaktadır.

Bu tanımlamalar ve yaklaşımlardan da anlaş1labileceği gibi Suriye'den zorunlu göç eden birçok kişi ne göçmen ne de mülteci veya sığınmacı olarak görülmektedir. Ancak farklı tanımlamalara göre farklı uygulamaların olduğu gözlemlenmektedir. Buna yönelik olarak Avrupa ve Türkiye arasında farklılıklar bulunmakta hatta, Avrupa Birliğinde de benzer şekilde göç ve sığınma konularında ortak bir politika bulunmamaktadır. Her ülkenin bu konulara farklı şekillerde eğildiği görülmektedir. Ancak birliğe üye ülkelerin uyması gereken bir takım ortak kurallar bulunmaktadır.

Tüm bunlara rağmen Suriye'den göç halen sürmektedir. Çoğunlukla Türkiye'ye gelen Suriyeli bireylerin belirli bir kısmı da bu süreç içinde Türkiye'yi transit bir ülke olarak kullanıp Avrupa'ya da çeşitli yolardan göç etmeye çalışmaktadır. Çoğunlukla yasa dışı olarak gerçekleştirilen bu göç sürecinde birçok kişi Türkiye-Yunanistan arasında bulunan Ege denizinde boğularak hayatını kaybetmiştir. Diğer taraftan Balkanlar üzerinden orta Avrupa'ya doğru giden bazı Suriyeliler sınırlarda bekletilmiş veya Yunanistan'a bir şekilde ulaşan bazı Suriyeliler ise daha sonradan Türkiye'ye geri gönderilmiştir. Avrupa ülkelerinin yine birçoğu kaçak olarak gelen bazı Suriyelileri Türkiye'ye iade etmektedir. Buna yönelik olarak AB ve Türkiye arasında 16 Aralık 2013 tarihinde imzalan ve 20 Mart 2016'da yürürlüğe konan "Geri Kabul Anlaşması” yapılmıştır. Bu anlaşmaya göre düzensiz olarak yapılan göç sorununu çözmek adına Türkiye'ye iade edilen bir Suriyeliye karşılık, Türkiye'de geçici koruma statüsünde bulunan Suriyelilerden biri AB ülkelerinden birine yerleştirilecektir. AB'den bu sürece yönelik Türkiye'ye birkaç milyar Euro yardım edildiği de bilinmektedir. Hatta çeşitli uluslararası ve ulusal örgüt ve yardım kuruluşları buna yönelik olarak Türkiye'de faaliyetlerini sürdürmektedir.

Yalnızca Türkiye'de yapılan yardımlara bakılacak olursak; AFAD barınma merkezlerinde 80.742 çocuk eğitim almaktadır, MEB ile yapılan ortak çalışmada ise 508.846 çocuk sokaklardan alınarak okullara yerleştirilmiştir, yine AFAD verilerine göre, bugüne dek Suriye ve Iraklı sı̆̆ınmacıların tedavileri kapsamında 953.466 bin ameliyat gerçekleştirilmiş; 1.143 .393 yatan hasta ve 25.919.750

Muhakeme Dergisi/Journal 2(1): 99-124, 2019 
milyon poliklinik hizmeti verilmiştir, 224.750 bebek Türkiye'de doğmuştur (AFAD, Ağustos 2017). Bunlar yalnızca Türkiye verileri, bu verilere bir de dünya geneli rakamlar eklendiğinde durum daha da vahim hale gelmektedir.

UN DESA 2017 verilerine göre, Türkiye'ye ait bilgiler şu şekildedir (UN-Desa, 2017):

Tablo 3 UN DESA Türkiye 2017 Göçmen Verileri

\begin{tabular}{|l|l|}
\hline Toplam göçmen sayısı & $\mathbf{4 , 9}$ Milyon \\
\hline Dünya'daki toplam göçmen nüfusa oranı & $\mathbf{6 \%}$ \\
\hline & \\
$\begin{array}{l}\text { Kadın göçmenlerin Türkiye'deki toplam göçmen } \\
\text { nüfusuna oranı }\end{array}$ & $\mathbf{5 3 \%}$ \\
\hline \begin{tabular}{l} 
19 Yaş altı göçmen sayısının toplama oranı \\
\hline
\end{tabular} & $\mathbf{2 8 , 8 0 \%}$ \\
\hline
\end{tabular}

Bu sayılara bakıldığında ise Türkiye'de toplam göçmen sayısının Suriyelilerle birlikte 4,9 milyona çıktığı görülmektedir. Dünyadaki toplam göçmen nüfusunun yüzde 6'sı Türkiye'de bulunmaktadır. Kadın göçmen sayısı ise toplam göçmen sayısının yarısından fazla olarak görülmektedir. 4/1'inden fazlası da 19'yaş altı yani büyük bir oranda çocuk da göçmenler arasındadır. Bu durumda aslında göç eden çok büyük bir çoğunluğun kadın ve çocuklardan oluştuğunu göstermektedir. Küçük de olsa bu orana yaşlı nüfusu eşlik etmektedir. Öte yandan Türkiye'nin 1961'den bu yana göçmen verileri incelendiğinde en büyük artışın 2009-2016 tarihlerinde olduğu gözlemlenmektedir. Bu da bu verilerin çok büyük bir çoğunluğun 2011'de patlak veren Suriye iç savaşından Türkiye'ye sığınan Suriyelilerin ait olduğunu göstermektedir.

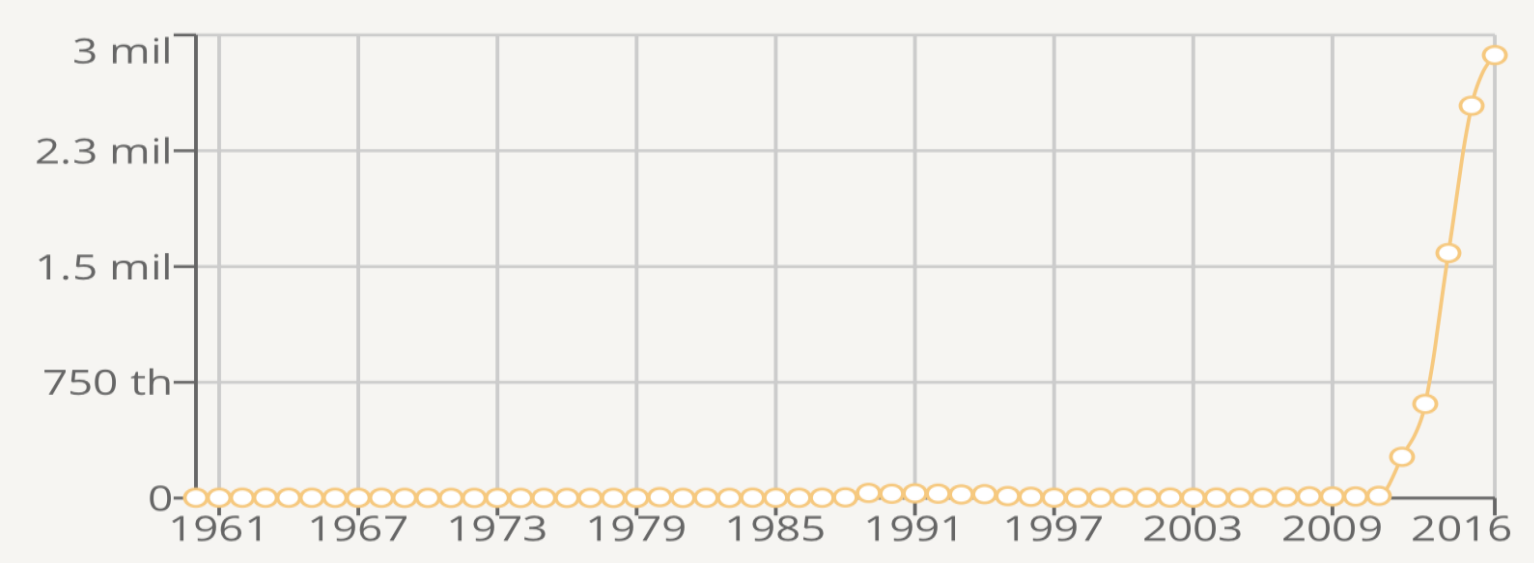

Şekil 1. Birleşmiş Milletler Mülteciler Yüksek Komiserliği (UNHCR) Türkiye 2016 mülteci verileri Kaynak: https://migrationdataportal.org/?i=stock_abs_\&t=2017\&cm49=792 Son Erişim Tarihi: 03.04.2018

Öte yandan yine AFAD’ın yapmış olduğu “Türkiye'deki Suriyelilerin Demografik Görünümü, Yaşam Koşulları ve Gelecek Beklentilerine Yönelik Saha Araştırması" adlı çalışmada çalışmaya dahil edilen 2435 adet Suriyelilere ait genel veriler şu şekildedir (AFAD, 2017):

- $\quad$ Yüzde 51'i asal yaş grubu olan 19- 54 yaş grubuna dahildir. Bunu yüzde 31 ile 0- 12 yaş arasındaki çocuklar ve yüzde 13 ile 13- 18 yaş grubundakiler izlemektedir. 
- $\quad$ Yüzde 23'ü okuryazar olmadığını ifade etmiştir (6 yaş ve üzeri bireyler arasında). İlkokul mezunu olanların oranı yüzde 26 düzeyinde iken en az üniversite düzeyinde eğitim görenlerin oranı yüzde 8 civarındadır.

- $\quad$ Yüzde 51'i Halep'ten, yüzde 11'i İdlip'ten yüzde 7'si Hama'dan ve yüzde 6's1 Lazkiye'den gelmiştir.

- $\quad$ Yüzde 80’i güvenlik/hayati tehlike nedeniyle ülkesinden ayrılmıştır. Bunu yüzde 12 ile siyasi nedenler izlemektedir.

- Yüzde 54'ü ulaşım kolaylığı nedeniyle Türkiye'yi tercih etmişken yüzde 27'si Türkiye'ye güvendiği için başka bir ülke yerine Türkiye'yi tercih etmiştir.

- $\quad$ Yüzde 42'si iki yıldan daha uzun süre önce Türkiye'ye geldiğini belirtmiştir. Kamp içindeki Suriyelilerde bu oran yüzde 83 ve kamp dışındaki Suriyelilerde ise yüzde 38 seviyesindedir.

- Yüzde 23'ü Türkiye'de kaldığı süre içerisinde Suriye'ye giriş/çıkış yapmıştır. Bu oranlar kamp içinde yüzde 45 iken kamp dişında yüzde 21 düzeyindedir.

- $\quad$ Giriş/çıkış yapanların yüzde 53'ü yakınlarını ziyaret etmişken yüzde 32'si Suriye'de kalan ev/mal varlığını kontrol etmiştir.

- $\quad$ Yüzde 83'ü Suriye'de iken aylık gelirlerinin 75 dolardan daha az olduğunu ifade etmiştir.

- Yüzde 30'u Türkiye'ye geldiklerinden beri hanelerinden en az bir bireyin borçlandığını belirtmiştir. Temel borçlanma sebebi olarak yüzde 64 ile ev kirası ilk sırada gelirken bunu yüzde 24 ile yiyecek temini izlemektedir.

- Yüzde 75'i Türkiye'de hangi koşullarda ve sektörlerde çalışabilecekleri konusunda yeterli bilgiye sahip değildir.

- Yüzde 36'sı herhangi bir sivil toplum kuruluşundan ayni/nakdi yardım aldığını ifade ederken yüzde 30'u ise devlet kurumlarından yardım aldığını belirtmiştir.

- $\quad$ Yüzde 29'unun Suriye'de kalan evleri y1kık durumda iken yüzde 23'ünün evi ise çok hasarlı durumdadir.

- $\quad$ Yüzde 76'sı Suriye'deki yakınları ile iletişimini internet üzerinden sürdürmektedir. Yüzde 42'si haftada bir ya da birkaç kez görüşme imkânı bulduklarını ifade etmiştir.

- Yüzde 36'sının hanesinden en az bir kişi iç karışıklıklarda hayatını kaybetmiştir. Hanesinden en bir kişinin yaralandığını ifade edenlerin oranı ise yüzde 29 seviyesindedir.

- $\quad$ Yüzde 52'si meskeninin büyüklüğünü, yüzde 51'i konforunu, yüzde 62'si güvenliğini, yüzde 54'ü sağlamlığını, yüzde 45'i iklime uygunluğunu ve yüzde 48'i ise aile hayatına uygunluğunu yeterli görmektedir. Kamp içindeki yeterlilik oranları kamp dışına göre daha yüksektir.

- Yüzde 37'si yakıtlarının, yüzde 57'si gıda malzemelerinin, yüzde 55'i uyku malzemelerinin, yüzde 43'ü mobilyalarının, yüzde 59'u giyim malzemelerinin, yüzde 77'si ibadet malzemelerinin ve yüzde 45 'i de sosyal malzemelerinin yeterli olduğunu ifade etmiştir. Genel yeterlilik oranı kamp içinde yüzde 78 iken kamp dışında yüzde 51 düzeyindedir.

- $\quad$ Yüzde 57'si önümüzdeki yedi gün için yeterli yiyeceğe ya da yiyecek temin edebilecek paraya sahip olduklarını belirtmiştir.

- Yüzde 66'sı Türkiye'deki sağlı hizmetlerinden faydalandığını ifade etmiştir. Sağlık hizmetlerinden memnuniyet oran1 yüzde 83 düzeyindedir.

- Yüzde 59'u gerektiğinde ilaca erişim sağlayabildiklerini ifade etmiştir. Kamp içinde ilaca erişim oranları kamp dışına göre daha yüksektir.

- Yüzde 58'i kendilerinin veya aile üyelerinin psiko-sosyal desteğe ihtiyaç duymadığını belirtmiştir.

- Yüzde 16'sı Suriye'ye dönmeyi düşünmediğini ifade ederken yüzde 35'i Suriye'deki karışıklıklar sona erdiğinde ülkesine döneceğini vurgulamıştır.

- Yüzde 25'i Suriye'deki iç karışıkların yakın bir gelecekte sona ermeyeceğini düşünmektedir.

- $\quad$ Yüzde 30'u geleceğinden umutsuz olduğunu belirtmiştir.

- Yüzde 41'i Türkiye'deki Suriyelilerin yarısının Türkiye de kalıcı olacağını belirtmiştir. Tamamının döneceğini düşünenlerin oranı yüzde 10 düzeyindedir.

- Yüzde 51'i Türkiye'den daha iyi startlara sahip olduğunu düşündüğü üçüncü bir ülkeye gitmeye istekli olmadıklarını belirtmiştir. 
- Yüzde 21'i Türkiye'deki sosyal hayata uyum sağlayamadığını ifade etmiştir.

- $\quad$ Yüzde 44'ü kültür farklılığının, yüzde 40'1 sosyal hayata ilişkin farklılıkların, yüzde 29'u ahlaki farklılıkların, yüzde 18'i dini yaşama ilişkin farklılıkların, yüzde 60'1 savaşın yarattığ1 psikolojinin ve yüzde 72'si ise maddi yetersizliklerin uyum sağlamanın önünde engel teşkil ettiğini ifade etmiştir.

- $\quad$ Yüzde 33'ü kendilerini topluma ait hissetmediklerini ifade etmiştir.

- Yüzde 41'i konut fiyatlarının ve kiralarının, yüzde 19'u toplumsal huzurun, yüzde 16's1 asayişin, yüzde 21 'i iş olanaklarının ve maaşların Suriyelilerin gelişi ile birlikte olumsuz yönde etkilendiğini düşünmektedir.

- Yüzde 37'si resmi olarak geçici koruma statüsü altında yasadıklarını ifade etmişken yüzde 35'i ise mülteci statüsüne sahip olduklarını düşünmektedir.

- Yüzde 64'ü Suriyeliler ile Türklerin akrabalık ilişkisi içinde bulunmasını olumlu karşılamaktadır.

AFAD'ın 2014'te kadınlara yönelik yaptığı diğer bir araştırmaya göre (AFAD, 2014):

- Suriyeli kadınların yüzde 35'i iç savaş nedeniyle en az bir yakınını kaybettiğini, yüzde 28'i ise en bir yakınının iç karışıklık nedeniyle yaralandığını belirtmiştir.

- $\quad$ Suriyeli kadınların yüzde 91'i Suriye'deki yakınları ile mobil telefonlar aracılığıyla iletişim kurmaktadir.

- $\quad$ Suriyeli kadınların yarısından fazlası, kendisinin veya aile bireylerinin psikolojik desteğe ihtiyacı olduğunu ifade etmiştir.

- Kamp içinde yaşayan misafirlerin yarıya yakını hanesinde uyku bozukluğu yaşayan çocuk olduğunu ifade etmiştir.

- $\quad$ Kamp dışında yaşayan Suriyeli kadınların yaklaşık yüzde 73 gibi büyük bir çoğunluğu ev ya da apartman dairesinde yaşadığını belirtmiştir.

- $\quad$ "Önümüzdeki 7 gün için yeterli yiyeceğe ya da yiyecek temin edebilecek paraya sahip misiniz?” sorusuna kadınların yüzde 78'i hayır cevabını vermiştir.

- $\quad$ Başka bir ülke yerine Türkiye'yi tercih etme nedeni olarak kadınların yüzde 82'si ulaşım kolaylığını göstermiştir.

- $\quad$ Kamp içindeki kadınların yüzde 94'ü ve kamp dışındaki kadınların yüzde 93'ü Türkiye'deki insanların kendilerine karşı davranışlarını olumlu olarak değerlendirmektedir.

- Kamp dışında yaşayan Suriyeli misafirlerin meskenlerindeki temel ihtiyaçlarının, kamp içinde yaşayan Suriyeli misafirlere kıyasla yeterlilik oranları daha azdır.

- Türkiye'deki sağlık hizmetlerinden faydalanan kadınların, bu hizmetlerden duydukları memnuniyet oranı, kamp içinde yüzde 60 ve kamp dışında yüzde 80 seviyesindedir.

- Kadınların hemen hemen yarısına yakını imkân sağlansa da üretime katılmak istemediklerini belirtmişlerdir.

Öte yandan şekil 2 ve 3'te görülebileceği üzere kamp içi gelenlerin yarısından fazlasının İdlip, Halep ve Lazkiye şehirlerinden, kamp dışı gelenlerin ise Halep, Rakka, Hasiçi'den geldiği görülmektedir. Buradaki temel farklılık Halep ve Rakka'da yaşanan çatışma sırasında acil olarak şehri boşaltan kitlenin yasa-dışı yolardan Türkiye'ye giriş yapmak zorunda kalması olarak anlaşılmaktadır. Bu da aslında kontrollü olarak gerçekleşen göç ve kontrolsüz olarak gerçekleşen göç hakkında fikir vermektedir. Buna göre pek çok insanın zor koşullar altında kalarak ülkesini aniden terk etmek zorunda kaldığını, verilen yaşam mücadelesinin bir yansıması olarak değerlendirebiliriz. 


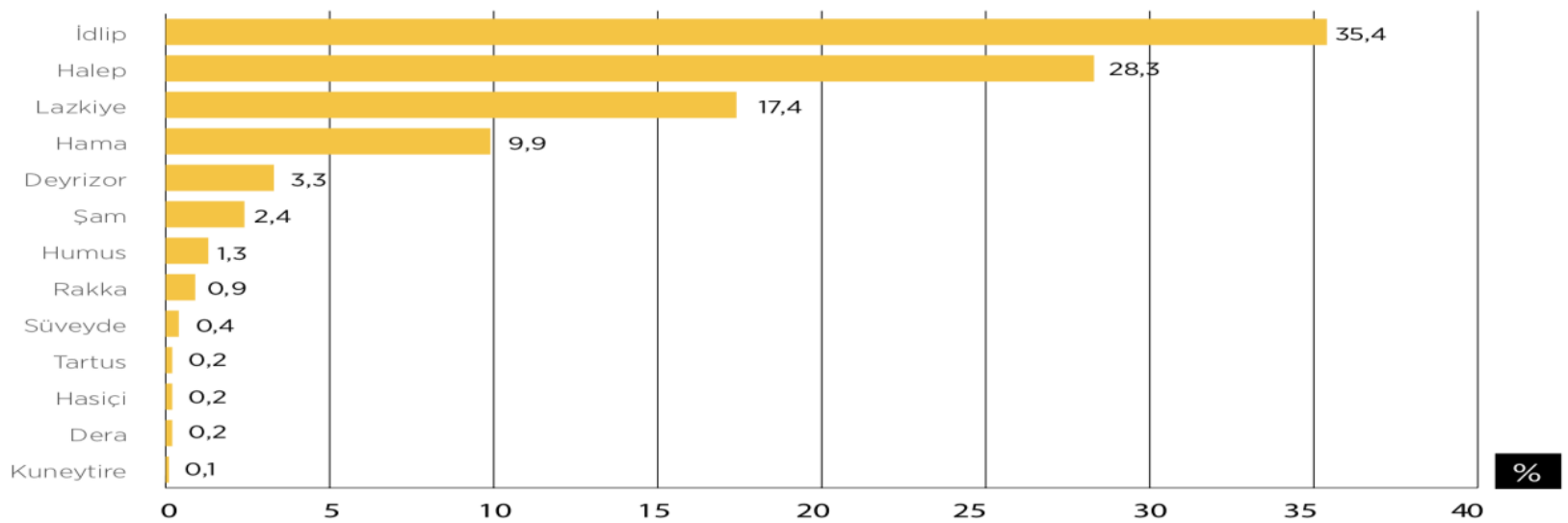

Şekil 2. Kamp içinde yaşayan Suriyeli kadınların geldikleri suriye kentlerinin dağılımı, kamp-içi (AFAD, 2014).

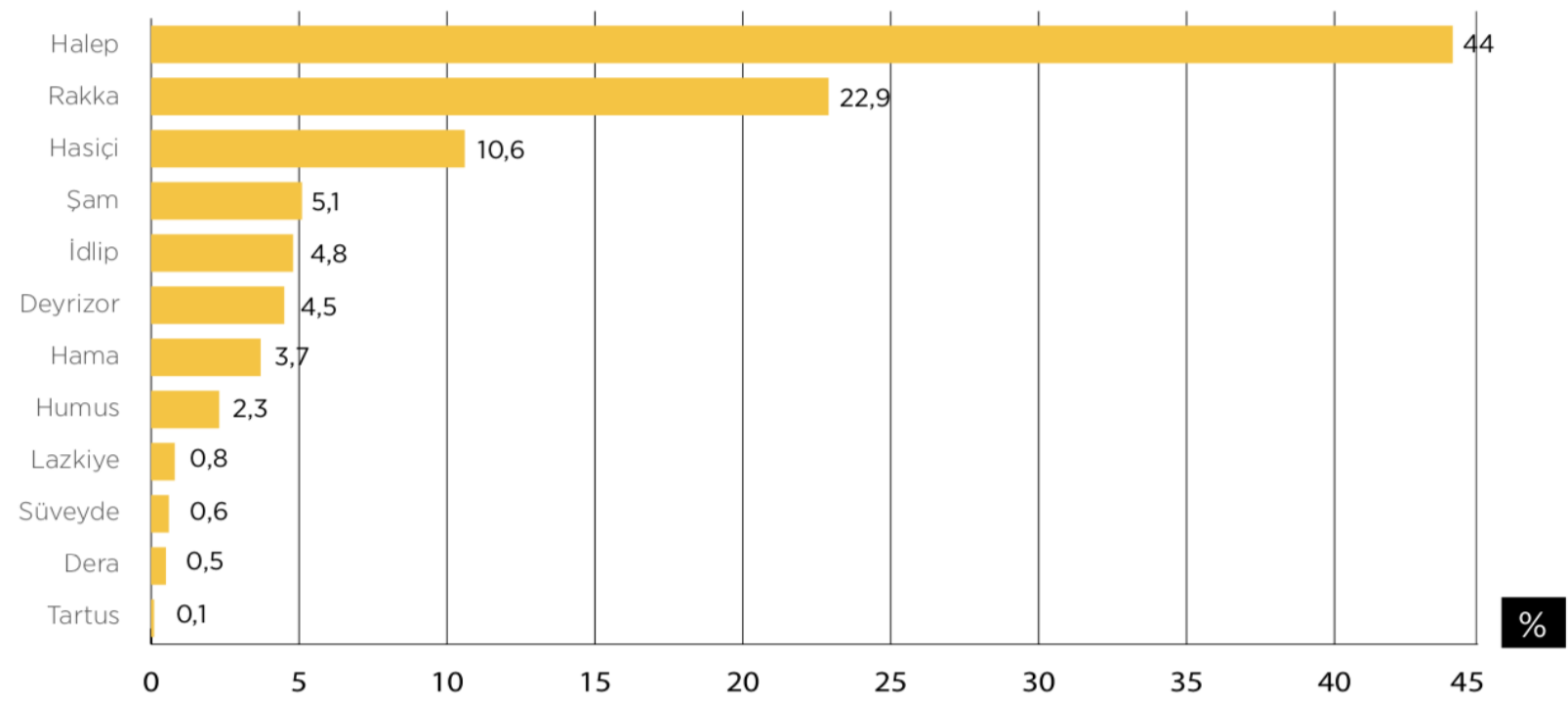

Şekil 3. Kamp dışında yaşayan Suriyeli kadınların geldikleri suriye kentlerinin dağılımı, kamp-dışı (AFAD, 2014).

Tüm bu veriler ışı̆̆ında kadınların göç sürecinde pek çok açıdan zorluklarla mücadele etmek zorunda kaldığı çıkarımına varmaktayız. Özellikle kadınların yüzde 78 gibi büyük bir oranının yiyecek ve içecek alacak paralarının olmadığını ifade etmesi, temel ihtiyaçlar düzeyinde de sıkıntılar yaşandığını göstermektedir. Çocukların uyku bozukluğu gibi sağlık problemlerinin olması hem psikolojik hem de travmatik başka sağlık problemlerine işaret etmektedir. Bu konuda yarıya yakın bir sayının verilmiş olması savaş sonrası göç eden kitlenin çocuklarının bu durumdan büyük oranda olumsuz etkilendiği görülmektedir. Yine büyük bir oranda psikolojik desteğe ihtiyaç duymaları savaşın psiko-sosyal olumsuz etkisine vurgu yapmaktadır.

Yine şekil 5'te görülebileceği üzere kadınların sınırdan geçiş biçimleri hatırı sayılır bir oranda yasadışı yolardan gerçekleşmiş̧ir. 


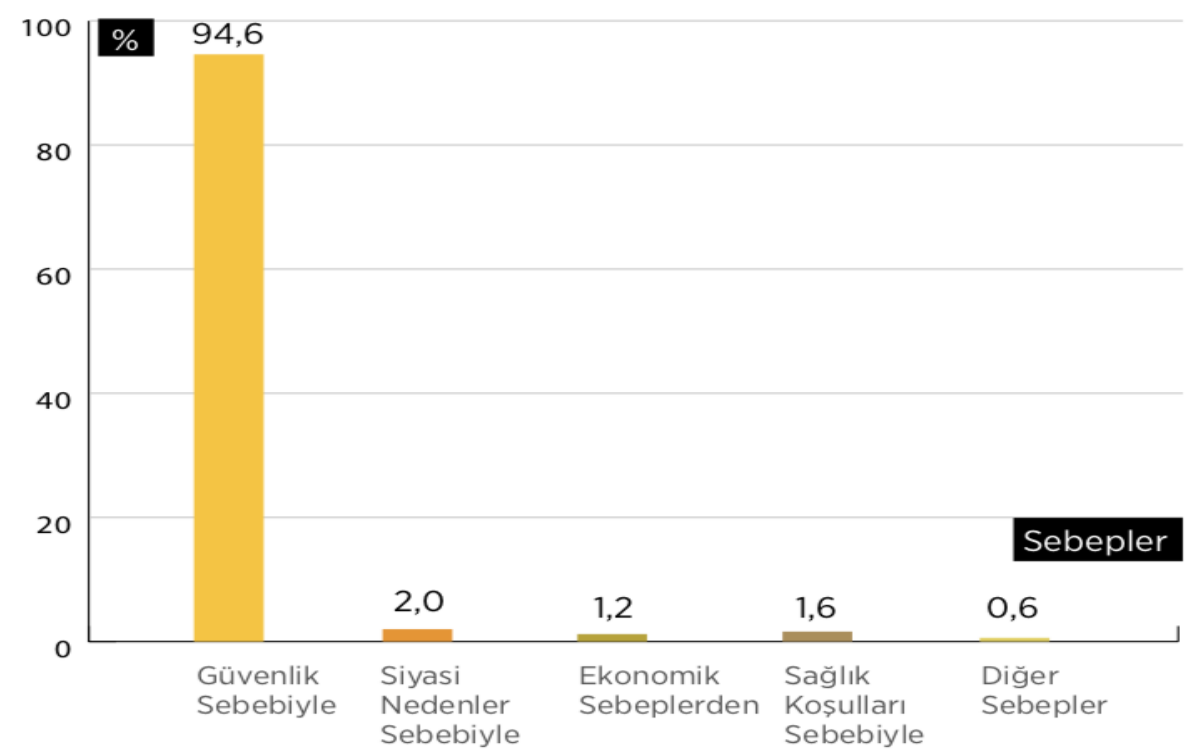

Şekil 4. Suriyeli kadınların Suriye'den ayrılış sebepleri (AFAD, 2014).

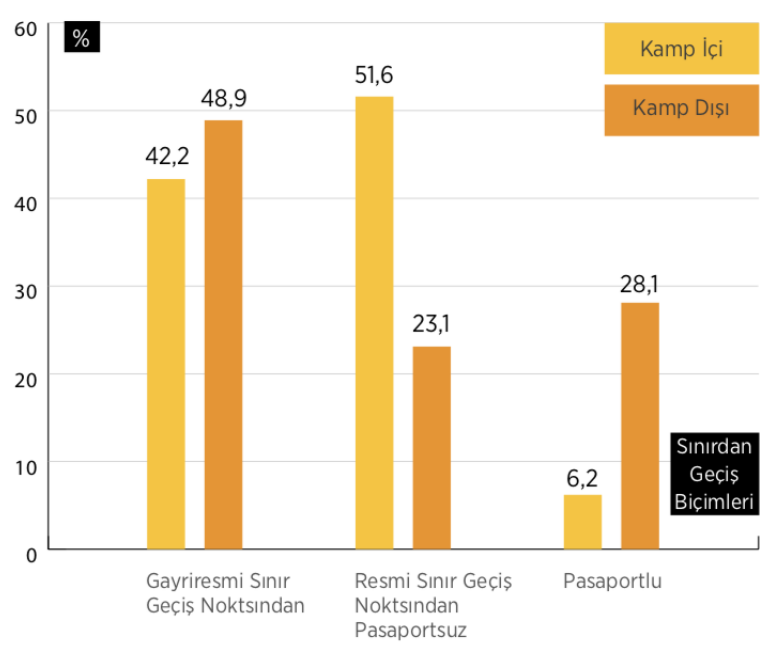

Şekil 5. Kadınların sınırdan geçiş biçimleri (AFAD, 2014).

\section{SONUÇ ve TARTIŞMA}

Giderek çetinleşen savaş koşulları sürekli artan bir göç popülasyonunu da beraberinde getirmektedir. Ancak bununla birlikte göç eden Suriyeliler için de daha önce hiç bilmedikleri bir coğrafyada, hiç kullanmadıkları yabancı bir dilde, alışık olmadıkları bir kültürde ve tamamen geride bıraktıkları Suriye'deki hayatları ile bir yaşam mücadelesi sürecine girmişlerdir.

Göçün kadın üzerindeki etkileri, göç alan yazınında kadın, birçok kesim tarafından ele alınmış; kimilerince yeterli bulunmamış ve eleştirel olarak ele alınmıştır. Özellikle eril bakış açısı ile kadının görmezden gelinişi bazı yazarlar tarafından eleştirilmiş, özellikle feminist yazarlar tarafından eleştirel bir bakış açısı ile tekrardan yorumlanarak kadın konusunu görünür hale getirmeye çalışılmıştır. Yapılan bu çalışmalarda kadının edilgen olmadığına yönelik eleştiriler birçok yazar tarafından dile getirilmiştir. Göç konusu hali hazırda gündemde ve tartışılagelen bir konu iken ve bu süreçte kadının yaşadığı sorunlar ele alınırken Suriye iç savaşı ile birlikte gün yüzüne çıkan tabloda kadın ve çocukların bu savaşın etkilerinden büyük oranlarda olumsuz yönde etkilendiği görülmektedir. Bir sürü ulusal ve uluslararası örgütün, kuruluşların ve siyasilerin gündeminde olan bu konu, çok farklı açılardan ele alınarak tartışılmaktadır. Özellikle Türkiye hem bir transit ülke konumunda olması hem de en fazla "geçici koruma" altındaki popülasyonuna sahip olması itibariyle bu örgütlerin faaliyetlerini yürüttükleri, çalışmalarını yoğunlaştırdıkları hatta yardımlarla destek olmaya çalıştıkları bir ülke 
konumundadır. IOM, ASAM, BM, ILO, UNCHR, UNICEF gibi örgütlerle birlikte AB üyesi ülkeler, Orta doğu ülkeleri, ABD ve Rusya gibi büyük çapta ülkeler Türkiye'yi bu konuda takip etmekte ve karş1lık olarak Türkiye'de birçok konuda Suriyeliler konusunda büyük sözün sahibi ülke olarak hareket etmektedir.

Özellikle kadın ve çocuk konusu birçok açıdan ön plana çıkmakta, üzerine daha fazla durulması ve çalışma yapılması gereken bir konu olarak karşımıza çıkmaktadır. Savaş ortamında çocuklar, gelişim çağının en hızlı oldukları dönemde travmatik sahnelerle karşı karşıya kalmakta ve kalıcı izler bırakan deneyimleri çok küçük yaşta edinmektedirler. Bu sorunlar özellikle Türkiye ve dünya için gelecekte birçok sorun ve suç vakalarını beraberinde getirmesi kaçınılmaz görünmektedir. Eğitim alması gereken yaşlarda, kamplarda veya sokaklarda çok zorlu koşullarda büyüyen çocuklar hem sağlik hem psikolojik hem de maddi-manevi sayısız anlamda sorunla yüz yüze gelmekte, çoğu zamanda iç burkan hikayeleri ile toplum vicdanını ve/veya bireysel olarak bizleri derinden sarsmaktadır. Ayla bebek gibi medya da yer alan haber, fotoğraf ve diğer paylaşımlar psikolojik açıdan, tersine Türk ve diğer dünya vatandaşlarının da sağlığını tehdit etmektedir.

Göç olgusu ile birlikte ele alınan kadın ve çocuk konusu Suriye iç savaşı ve sonrasında yaşanan göç durumu kapsamında ele alınmaya çalışılmış ve sürecin hem kadınlar hem de çocuklar nezdinde olumsuz sonuçları olduğu anlaşılmıştır. Bu bağlamda savaş gibi pek çok sosyo-ekonomik sorunları beraberinde getiren ve insani olmayan durumların tekrarlanmaması, yaşanan olumsuz durumların düzeltilebilmesi için ivedi bir şekilde tüm dünyada ortak kararların ve önlemlerin alınması önemli hale gelmektedir. İstatistiki verilerde yer alan sayıların birer insan hayatı olarak, her birinin ayrı ve tek başına da değerli olduğu şeklinde ele alınması gerektiği, sayıların küçüklügünün yaşanan olumsuzlukları ve travmatik durumları küçültmediği unutulmamalıdır.

\section{KAYNAKÇA}

Çakran, Ş., \& Eren, V. (2017). Mülteci Politikası: Avrupa Birliği ve Türkiye Karşılaştırması. Mustafa Kemal Üniversitesi Sosyal Bilimler Enstitüsü Dergisi, 14(39), 1-30.

Çetin, İ. (2016). Suriyeli Mültecilerin İşgücüne Katılımları ve Entegrasyonu: Adana-Mersin Örneği. Gaziantep Üniversitesi Sosyal Bilimler Dergisi, 15(4), 1001-1016.

Çiftçi, E. (2011). Dünya Harp Traihi. Blogspot: http://dunyaharptarihi.blogspot.com.tr/2010/09/kadessavasi-mo-1274.html Erişim Tarihi: 01.10.2017

Achar, B. N. (2012). Historicity of Mahabharata War: Astronomical Methods Using Planetarium Software.

draupaditrust.org:

http://www.draupaditrust.org/content/International\%20con/Mahabharata/Prof\%20B.\%20N.\%20Naraha ri\%20Achar.pdf Erişim Tarihi: 10.10.2017

AFAD. (2014). Türkiye'deki Suriyeli Kadınlar. Ankara: Başbakanlık Afet ve Acil Durum Yönetimi Başkanlığı.

AFAD. (2017). Türkiye’deki Suriyelilerin Demografik Görünümü, Yașam Koșulları ve Gelecek Beklentilerine Yönelik Saha Araștırması. Ankara: Başbakanlık Afet ve Acil Durum Yönetimi Başkanlığı.

AFAD. (2018). Suriye GBM Bilgi Notu. Ankara: T.C. Başbakanlık Afet ve Acil Durum Yönetimi Başkanlığı.

AFAD. (2017). Suriyeli Sı ğınmacılara Yapılan Yardımlar. Ankara.

Agcadağ Çelik, İ., \& Vural, F. (2018). Suriyeli Mülteci Kadınların Kuma Dramı: Kilis İli Örneği. Uluslararası Toplum Araştırmaları Dergisi, 8(14), 341-382.

Avşar Kurnaz, Ş. (2007). Çocuk Yoksulluğu. Aile ve Toplum, 9(3), 47-55.

Muhakeme Dergisi/Journal 2(1): 99-124, 2019 
Aydın, D., Şahin, N., \& Akay, B. (2017). Göç Olayının Çocuk Sağlığı Üzerine Etkileri. İzmir Dr. Behçet Uz Çocuk Hast. Dergisi, 7(1), 8-14.

Baş, M., Molu, B., Gör, A., Tuna, H., \& Baş, İ. (2017). Göç Eden Ailelerin Sosyo-Kültürel Ve Ekonomik Değişiminin Kadın ve Çocuk Yaşamına Etkisi. Insan ve Toplum Bilimleri Araştırmaları Dergisi, 6(3), 1680-1693.

Balcılar, M. (2016). Türkiye'deki Suriyeli Mültecilerin Sağlık Durumu Araştırması Türkiye'de Yaşayan Suriyeli Mültecilerde Bulaşıcı Olmayan Hastalık Risk Faktörleri Sıklı̆̆ı. AFAD, T.C.Sağlık Bakanlığı, World Health Organisation.

Berger, R. (2004). Immigrant Women Tell Their Stories. New York: The Haworth Press.

BM. (1989). Çocuk Haklarına Dair Sözleşme. UNICEF: https://www.unicef.org/turkey/\%C3\%A7ocuk-haklar\%C4\%B1na-dair-s\%C3\%B6zle\%C5\%9Fme Erişim Tarihi: 01.11.2018

Bretel, C. B., \& Sargent, C. F. (2008). Gender in Cross Cultural Perspective. Singapore: Pearson Higher Ed.

Buz, S. (2007). Göçte Kadınlar: Feminist Yaklaşım Çerçevesinde Bir Çalışma. Toplum ve Sosyal Hizmet, 18(2), 37-50.

Buz, S. (2009). Göç ve Kentleşme Sürecinde Kadınların "Görünürlüğü". Aile ve Toplum, 5(17), 40-50.

Cameron, S., \& Newman, E. (2008). Trafficking in Humans: Social, Cultural and Political Dimensions. United Nations University Press.

Children In Migration. (2018). Europian Commission: https://ec.europa.eu/info/policies/justice-andfundamental-rights/rights-child/children-migration_en Erişim Tarihi: 23.02.2018

Christian, T. (2012). What was the first known war in history? History-StockExchange: https://history.stackexchange.com/questions/2210/what-was-the-first-known-war-in-history Erişim Tarihi: 23.02.2018

Coşkun, E. (2017). Türkiye'de Kağıtsız Göçmen Kadınlar ve Sosyal Hizmetler. Çalışma ve Toplum Dergisi, 54(3), 1299-1315.

Demirdezen, D. (2013). Türkiye'de Ev Hizmetlerinde Çalışan Göçmen Kadınlar: Yeni Düzenlemelerle Yarı Köle Emeğine Doğru mu? Çalışma ve Toplum, 38(3), 325-346.

Doğanay, H., Şahin, İ. F., \& Özdemir, Ü. (2007). Feminist Coğrafya ve Kadın Göçmenler. Doğu Coğrafya Dergisi, 12(17), 7-16.

Dw.com. (2017). Suriye'deki savaşta ölü sayısı 340 bini geçti. Deutsche Welle Türkçe: http://www.dw.com/tr/suriyedeki-savaşta-ölü-sayıs1-340-bini-geçti/a-41523980 Erişim Tarihi: 23.02.2018

E-Bilge. (2010). Tarihin ilk savaşı ne zaman ve nerede yapılmıştır? Kaç kişi katılmıştır? https://www.ebilge.com/344225/Tarihin_ilk_savasi_ne_zaman_ve_nerede_yapilmistir_Kac_kisi_katil mistir.html Erişim Tarihi: 23.02.2018

Edzard, D. O., Frye, R. N., \& Soden, W. T. (2018). History of Mesopotamia. Encyclopædia Britannica: https://www.britannica.com/place/Mesopotamia-historical-region-Asia Erişim Tarihi: 23.02.2018

Ekici, S., \& Tuncel, G. (2015). Göç ve İnsan. Birey ve Toplum, 5(9), 9-22. 
El-Cherkeh, T., Stirbu, E., Lazararoiu, S., \& Radu, D. (2004). EU-Enlargement, Migration and Trafficking in Women: The Case of South Eastern Europe. Hamburgisches Welt-Wirtschafts-Archiv (HWWA).

Erdoğan, M. M. (2017). Urban refugees from detachment to harmonization syrian refugees and process management of municipalities: The case of Istanbul. http://fs.hacettepe.edu.tr/hugo/MMU\%20Urban\%20Refugees\%20Report\% 202017_en.pdf Erişim Tarihi: 23.02.2018

Gülçür, L., \& İlkkaracan, P. (2002). The "Natasha" Experience: Migrant Sex Workers from The Former Soviet Union and Eastern Europe in Turkey. Women's Studies International Forum, 411-421.

Gümüşten, D. (2017). Mülteci Çocukların Eğitimi ve Uyumlarına Yönelik Yapılan Müdahale Programları Üzerine Bir Derleme. Nesne Psikoloji Dergisi, 5(10), 247-264.

Güneysu, G. (2017). Feminist Uluslararası Hukuk ve Göç. Kadın ve Hukuk Sempozyumu.

Geçkil, E., Aldem, M., \& Kaleci, E. (2017). Göçün çocuk sağlığına etkisi. Journal of Human Sciences, 14(1), 171-186.

Genova, N. P. (2002). Migrant "Illegality" and Deportability in Everyday Life. Annual Reviews Antropology, 31, 419-47.

Gonca, A. (2002). Dünya Savaşının Tarihçesi... Haber Vitrini: http://www.habervitrini.com/gundem/dunyada-savasin-tarihcesi-50694 Erişim Tarihi: 23.02.2018

Guterres, A. (2018). Kadın Hakları Açısından Dünya Bir Dönüm Noktasında. (Birleşmiş Milletler) http://www.un.org.tr/kadin-haklari-acisindan-dunya-bir-donum-noktasinda/ Erişim Tarihi: 09.05.2018

Harding, S. (1996). Feminist yöntem Diye Bir Şey Var mı? Farklı Feminizmler Açısından Kadın Araştırmalarında Yöntem.

Hiott, A. E., \& Grzywacz, J. G. (2008). Migrant farmworker stress: mental health implications. J Rural Health, 24, 32-39.

Hodes, M. (2000). Psychologically distressed refugee children in the United Kingdom. Child Psychology \& Psychiatry Review, 5(2), 57-68.

İlhan, M. N., Gözlü, M., Atasever, M., Dündar, M. A., Büyükgök, D., \& Barkan, O. B. (2016). Göç ve Halk Să̆lı̆̆ . Ankara: Susam Yayınları.

ILO. (2017). Global Estimates of Child Labour. Alliance: https:/www.ilo.org/wcmsp5/groups/public/--dgreports/---dcomm/documents/publication/wcms_575499.pdf Erişim Tarihi: 23.02.2018

Ünlütürk-Ulutaş, Ç., \& Kalfa, A. (2009). Göçün Kadınlaşması ve Göçmen Kadınların Örgütlenme Deneyimleri. Fe Dergi, 13-18.

Ünlütürk-Ulutaş, Ç., \& Kalfa, A. (2009). Göçün Kadınlaşması ve Göçmen Kadınların Örgütlenme Deneyimleri. Fe Dergi: Feminist Eleştiri, 1(2), 12-27.

İnsan Hakları ve Mazlumlar İçin Dayanışma Derneği-MAZLUMDER. (2014). Kamp Dışında Yaşayan Suriyeli Kadın Sığınmacılar Raporu. http:// panel.stgm.org.tr/vera/app/var/files/m/a/mazlu mder-kampdisinda-yasayan-suriyeli-kadinsigin. Erişim Tarihi: 23.02.2018

IOM. (2018). Key Migration Terms. International Organization for Migration: https://www.iom.int/key-migration-terms Erişim Tarihi: 23.02.2018

Islam, M. M., \& Gagnon, A. J. (2016). Use of reproductive health care services among urban migrant women in Bangladesh. BMC Women's Health, 16(15). 
Kadın Merkezi Vakfi-KAMER. (2017). Siğınmacı Kadınlar Beş Il Raporu. http://www.kamer.org.tr/menuis/kamer_vakfi_s iginmaci_kadinlar_5_il_raporu.pdf. Erişim Tarihi: 23.02.2018

Kalkan, O., Gülay, M., Vatan, İ., Bakış, B., Engindeniz, F. T., \& Özyürek, M. M. (2014). Bursa İli Osmangaziilçesi'nde İkamet Eden Suriyeli Göçmenlerin Temel Sağlık Durumlarının Değerlendirilmesi. 17. Ulusal Halk Să̆llğg Kongresi, 457-458.

Kara, P., \& Nazik, E. (2018). Göçün Kadın ve Çocuk Sağlı̆̆ına Etkisi. Gümüşhane Üniversitesi Sağllk Bilimleri Dergisi, 7(2), 58-69.

Kaygısız, İ. (2017). Suriyeli Mültecilerin Türkiye İşgücü Piyasasına Etkileri. Friedrich Ebert Stiftung, http://www.fes-tuerkei.org/media/pdf/. Erişim Tarihi: 23.02.2018

Korkmaz, A. Ç. (2014). Sığınmacıların Sağlık ve Hemşirelik Hizmetlerine Yarattı̆̆ı Sorunlar. Sağllk ve Hemşirelik Yönetimi Dergisi, 1, 37-42.

Krause, S., Williams, H., Onyango, M. A., Sami, S., Doedens, W., \& Giga, N. (2015). Reproductive health services for Syrian refugees in Zaatri camp and Irbid city, Hashemite Kingdom of Jordan: An evaluation of the minimum initial services package. Conflict and Health, 9(4).

Lordoğlu, K., \& Aslan, M. (2016). En Fazla Suriyeli Göçmen Alan Beş Kentin Emek Piyasalarında Değişimi: 2011-2014. Çalışma ve Toplum, 2, 789-808.

Lordoğlu, K., \& Aslan, M. (2018). Görünmeyen Göçmen Çocukların İşçiliği: Türkiye'deki Suriye'li Çocuklar. Çalışma ve Toplum, 2, 715-732.

Mahler, S. J., \& Pessar, P. R. (2006). Gender Matters: Ethnographers Bring Gender from the Periphery toward the Core of Migration Studies. IMR: International Migration Review, 40(1), 27-63.

Mansfield, S. (1982). The Gestalt of War. New York: Dial Press.

Massey, D. S., Arango, J., Hugo, G., Kouaouci, A., \& Pellegrino, A. (2005). Worlds in Motion: Understanding International Migration at The End of The Millennium. Oxford: Clarendon Press.

ORSAM. (2015). Suriyeli Siğınmacıların Türkiye'ye Etkileri. http://www.unhcr.org/turkey/uploads/root/tr(48).pdf Erişim Tarihi: 23.02.2018

Polat, G. (2007). İç Göçün Çocuk Ruh Sağlığına Etkisi ve Sosyal Hizmet Müdahalesi. Toplum ve Sosyal Hizmet, 1, 89-106.

Ravenstein, E. G. (1885). The Laws of Migration . Journal of the Statistical Society of London, 48(2), 167-235.

Ravenstein, E. G. (1889). The Laws of Migration. Journal of the Royal Statistical Society, 52(2), 241305.

Resmî Gazete. (2013). Yabanclar ve Uluslararası Koruma Kanunu (YUKK). Ankara: Say1: 28615. Resmî Gazete. (2013). Say1: 28615.

Savaş ve Siyasal Şiddette Hafıza ve Toplumsal Cinsiyet Genç Araştırmacılar Konferansı. (2014). BildiriOzetleri, http://myweb.sabanciuniv.edu/genderconf/files/2014/04/GencArastirmacilarKonferansiBildiriOzetleri. pdf. Erişim Tarihi: 23.02.2018

Sayılarla Dünya Çocuklarının Durumu. (2014). Eşitsizliklerin Ortaya Konulması, Çocuk Haklarının Ileriye Götürülmesi. http://www.manevisosyalhizmet.com/wp-content/uploads/2014/05/unicef-dunyacocuklarinin-durumu-raporu2014.pdf Erişim Tarihi: 23.02.2018 
Selim, S. (2017). Türkiye'de Göç Kadınlaşıyor mu?: Ekonometrik Bir Analiz. Adnan Menderes Üniversitesi, Sosyal Bilimler Enstitüsü Dergisi, 4(3), 43-63.

Şeker, D., \& Uçan, G. (2016). Göç Sürecinde Kadın. CBÜ Sosyal Bilimler Dergisi, 14(1), 199-214.

Şen, A. B., \& Vural, C. (2014). Suriye İç Savaşında Göç ve Kadın. Yaratıcı Drama Dergisi, 9(17), 2940 .

Şimşek, Z., Doni, N. Y., Hilali, N. G., \& Yildirimkaya, G. (2017). A community-based survey on Syrian refugee women's health and its predictors in Şanliurfa, Turkey. Women \& Health, 1-15.

T.C.İ.B. (2005). Ilttica ve Göç Mevzuatı. Ankara: Başkent Matbaası.

Tekeli, İ. (1975). Göç Teorileri ve Politikaları Arasındaki İlişkiler. OTDÜ Mimarlık Fakültesi Dergisi, $1(1), 153-176$.

Tobler, W. (2013). Migration: Ravenstein, Thornthwaite, and Beyond. Urban Geography, 16(4), $327-$ 343.

Toksöz, G. (2008). Enformel İşgücü Piyasaları ve Göçmen İşçilere Talep: Karşılaştırmalı Perspektiften Türkiye'nin Durumu. Türkiye İşçi Sınıfi ve Emek Hareketi Küreselleşiyor mu? (s. 89-107). İstanbul: Sosyal Araştırmalar Vakfı (SAV), Türkiye Sınıf Araştırmaları Merkezi (TÜSAM).

Topcuoğlu, R. A. (2016). Göç Yazınındaki Düzenli ve Düzensiz Göç Kavramları: İnsan Hakları Temelinde Bir Kavramsal Sorgulama. Insan Hakları Yıllı̆̆l, 34, 1-20.

Tuzcu, A., \& Ilgaz, A. (2015). Göçün Kadın Ruh Sağlı̆̆ı Üzerine Etkileri. Psikiyatride Güncel Yaklaşımla, 7(1), 56-67.

Uçan Çubukçu, S. (2013). Küreselleşme, Göç ve Kadın Üzerine. Kadın Araştırmaları Dergisi, 12(1), 215-226.

UN-Desa. (2017). International Organization for https://migrationdataportal.org/?i=stock_abs_\&t=2017\&cm49=792 Erişim Tarihi: 03.04.2018

UNICEF. (2000). Poverty Reduction Begins with Children. New York: UNICEF.

UNICEF. (2002). Poverty and Children: Lessons of the 90s for Least Developed Countries. New York: UNICEF.

UNICEF. (2016). Nearly 385 Million Children Living In Extreme Poverty, Says Joint World Bank Group - UNICEF Study. https://www.unicef.org/press-releases/nearly-385-million-children-livingextreme-poverty-says-joint-world-bank-group Erişim Tarihi: 23.02.2018

UNICEF. (2016). Türkiye'deki Çocuklar. http://unicef.org.tr/files/bilgimerkezi/doc/T\%C3\%BCrkiyedeki\%20Suriyeli \%20\%C3\%87ocuklar_Bilgi\%20Notu\%20Nisan\%202016_1.pdf Erişim Tarihi: 23.02.2018

UNICEF. (2018). Children Uprooted. https://www.unicef.org/children-uprooted: UNICEF/UN0185401/Sanadiki. Erişim Tarihi: 23.02.2018

UNICEF: 85\% of Syrian children in Jordan live in poverty. (2018). MEMO: Middle East Monitor: https://www.middleeastmonitor.com/20180226-unicef-85-of-syrian-children-in-jordan-live-in-poverty/ Erişim Tarihi: 23.02.2018

Vardar, N. (2018). Mülteci, Göçmen, Sığınmacı Arasındaki Farklar? Bağımsız İletişim Ağı (BİANET): https://m.bianet.org/bianet/toplum/167434-multeci-gocmen-siginmaci-arasindaki-farklar Erişim Tarihi: 23.02.2018

Muhakeme Dergisi/Journal 2(1): 99-124, 2019 
Whynne-Hammond, C. (1985). Elements of Human Geography. Londra: Bell \& Hymann.

Wikipedia. (2018). Habil ve Kabil.

https://webcache.googleusercontent.com/search?q=cache:_jn6TXBSY9MJ:https://tr.wikipedia.org/wiki /Habil_ve_Kabil $+\& c d=6 \& h l=\operatorname{tr} \& c t=c l n k \& g l=t r$ Erişim Tarihi: 21.01 .2018

Wikipedia.

(2018).

Sümerler.

https://tr.wikipedia.org/wiki/S\%C3\%BCmerler\#S\%C3\%BCmerlerin_sonu Erişim Tarihi: 21.01.2018

Yağmur, Y., \& Aytekin, S. (2018). Mülteci Kadınların Üreme Sağlı̆̆ı Sorunları ve Çözüm Önerileri. Mülteci Kadınların Üreme Să̆lı̆g-DEUHFED 2018, 11(1), 56-60. 